\title{
Geological and morphological setting of 2778 methane seeps in the Dnepr paleo-delta, northwestern Black Sea
}

\author{
Lieven Naudts ${ }^{\text {a,* }}$, Jens Greinert ${ }^{\text {b }}$, Yuriy Artemov ${ }^{c}$, Peter Staelens ${ }^{\text {a, }}$, Jeffrey Poort ${ }^{\mathrm{a}, 1}$, \\ Pieter Van Rensbergen ${ }^{\mathrm{a}, 1}$, Marc De Batist ${ }^{\mathrm{a}, 1}$ \\ a Renard Centre of Marine Geology (RCMG), Universiteit Gent, Krijgslaan 281 s8, B-9000 Gent, Belgium \\ ${ }^{\mathrm{b}}$ Leibniz-Institut für Meereswissenschaften IFM-GEOMAR, Wischhofstrasse 1-3, 24148 Kiel, Germany \\ ${ }^{c}$ A.O. Kovalevsky Institute of Biology of the Southern Seas NAS of Ukraine, Pr. Nakhimov 2, 99011 Sevastopol, Ukraine
}

Accepted 25 October 2005

\begin{abstract}
The Dnepr paleo-delta area in the NW Black Sea is characterized by an abundant presence of methane seeps. During the expeditions of May-June 2003 and 2004 within the EU-funded CRIMEA project, detailed multibeam, seismic and hydro-acoustic water-column investigations were carried out to study the relation between the spatial distribution of methane seeps, sea-floor morphology and sub-surface structures.

2778 new methane seeps were detected on echosounding records in an area of $1540 \mathrm{~km}^{2}$. All seeps are located in the transition zone between the continental shelf and slope, in water depths of 66 to $825 \mathrm{~m}$. The integration of the different geophysical datasets clearly indicates that methane seeps are not randomly distributed in this area, but are concentrated in specific locations.

The depth limit for the majority of the detected seeps is $725 \mathrm{~m}$ water depth, which corresponds more or less with the stability limit for pure methane hydrate at the ambient bottom temperature $\left(8.9^{\circ} \mathrm{C}\right)$ in this part of the Black Sea. This suggests that, where gas hydrates are stable, they play the role of buffer for the upward migration of methane gas and thus prevent seepage of methane bubbles into the water column.

Higher up on the margin, gas seeps are widespread, but accurate mapping illustrates that seeps occur preferentially in association with particular morphological and sub-surface features. On the shelf, the highest concentration of seeps is found in elongated depressions (pockmarks) above the margins of filled channels. On the continental slope where no pockmarks have been observed, seepage occurs along crests of sedimentary ridges. There, seepage is focussed by a parallel-stratified sediment cover that thins out towards the ridge crests. On the slope, seepage also appears in the vicinity of canyons (bottom, flanks and margins) or near the scarps of submarine landslides where mass-wasting breaches the fine-grained sediment cover that acts as a stratigraphic seal. The seismic data show the presence of a distinct "gas front," which has been used to map the depth of the free gas within the sea-floor sediments. The depth of this gas front is variable and locally domes up to the sea floor. Where the gas front approaches the seafloor, gas bubbles were detected in the water column. A regional map of the sub-surface depth of the gas front emphasises this "gas front-versus-seep" relationship.
\end{abstract}

\footnotetext{
* Corresponding author. Tel.: +32 92644584; fax: +32 92644967.

E-mail address: Lieven.Naudts@UGent.be (L. Naudts).

${ }^{1}$ Tel.: +32 2644584; fax: +32 2644967.
} 
The integration of all data sets indicates that the spatial distribution of methane seeps in the Dnepr paleo-delta is mainly controlled by the gas-hydrate stability zone as well as by stratigraphic and sedimentary factors.

(C) 2005 Elsevier B.V. All rights reserved.

Keywords: methane seeps; seismic; gas front; gas hydrates; pockmarks; canyons; sedimentary ridges; methane derived carbonated cementation; Dnepr paleo-delta; Black Sea

\section{Introduction}

Gas seeps are widespread in the oceans and can be found on both active and passive continental margins ('cold seeps') and at ocean spreading centers ('hot vents') (Judd, 2003).

Cold seeps and gas seeps in general have engendered a substantial research effort worldwide because of their potential impact on the geosphere, the biosphere, the hydrosphere and the atmosphere (Judd, 2003). They can support unique endemic ecosystems of marine organisms (bacteria, tubeworms, clams, etc.) associated with authigenic carbonate or barite precipitation (Hovland et al., 1985; Boetius et al., 2000; Greinert et al., 2001; Michaelis et al., 2002; Greinert et al., 2002). Furthermore, seeps have an important economical value because they can be indications for shallow or deep hydrocarbon accumulations. These are not only interesting as possible energy sources but also have a large influence on the geotechnical properties of sediments and thus on the stability of the seabed. Shallow hydrocarbon reservoirs can also lead to blow-outs when reached during drilling operations (Sills and Wheeler, 1992). Recently, intensive research has focused on how gas seeps, methane seeps in particular, contribute to atmospheric methane concentrations and to the composition of the world oceans, and how they could affect global warming and the carbon cycle (Judd et al., 1997, 2002).

Seepage occurs where fluid flow is focused and where flux rates exceed utilizations rates allowing methane to pass through the seabed into the water column (Judd, 2003). However, under normal conditions, most of the methane will be oxidized by consortia of sulfate-reducing bacteria and methane-oxidizing archaea in anaerobic environments or by the aerobic activity of bacteria (Reeburgh et al., 1993; Boetius et al., 2000; Michaelis et al., 2002). Fluid migration can occur via conduits, such as fault zones, stratigraphic layers and mud diapirs (Hovland and Curzi, 1989; Moore et al., 1991), or by geomorphologically focused flow (Orange and Breen, 1992; Orange et al., 1994). This can be through diffusion of dissolved gas or by means of free-gas bubbles. Gas can also be a part of a gas-hydrate system (Kvenvolden, 1993). If pressure and/or temperature conditions change, gas hydrates can dissociate and hereby support gas seeps at the sea floor and result in sediment destabilization (Bouriak et al., 2000; Bünz et al., 2005).

With the recent increasing interest in gas seeps, detection tools and methods have been developed and adapted to discover and investigate seep sites. In addition to echosounder and high-resolution seismic recordings, multibeam and side-scan sonar have been used to detect gas seepage and shallow gas (Judd and Hovland, 1992; Wever et al., 1998). These methods are not only able to detect changes in morphology related to gas seepage (e.g. pockmarks, mud volcanoes) but also to detect changes in backscatter strength, which can provide strong indications for the presence of, for example, authigenic carbonates that are common at cold seeps (Greinert et al., 2001; Campbell et al., 2002). ROVs, submarines and CTDs have been used for groundtruthing, mapping and sampling sea-floor seeps (Orange et al., 2002; Suess et al., 2001; Johnson et al., 2003; Paull et al., 2005). Recent work also paid attention to the sub-surface with a focus on seismic sub-bottom signatures and indications of shallow gas (acoustic turbidity, enhanced reflections, acoustic blanking, etc.) and possible conduits (faults, diapirs, etc.), which can be indirect indications for seepage at the sea floor (Judd and Hovland, 1992; Orange and Breen, 1992; Yun et al., 1999; Garcia-Gil et al., 2002; Van Rensbergen et al., 2002, Krastel et al., 2003).

In this paper we present the discovery of thousands of active methane seeps detected directly with an adapted scientific split-beam echosounder. We were able to pinpoint the exact location of all seeps and to integrate the seep locations with the acquired multibeam and geophysical datasets to explain the observed seep distribution in relation to the geology and morphology.

\section{Study area}

The Dnepr paleo-delta area is located on the continental margin of the northwestern Black Sea, west of the Crimea Peninsula (Fig. 1). The area is well known for the abundant presence of shallow gas and gas seeps (Polikarpov et al., 1989, 1992; Egorov et al., 1998; Popescu et 


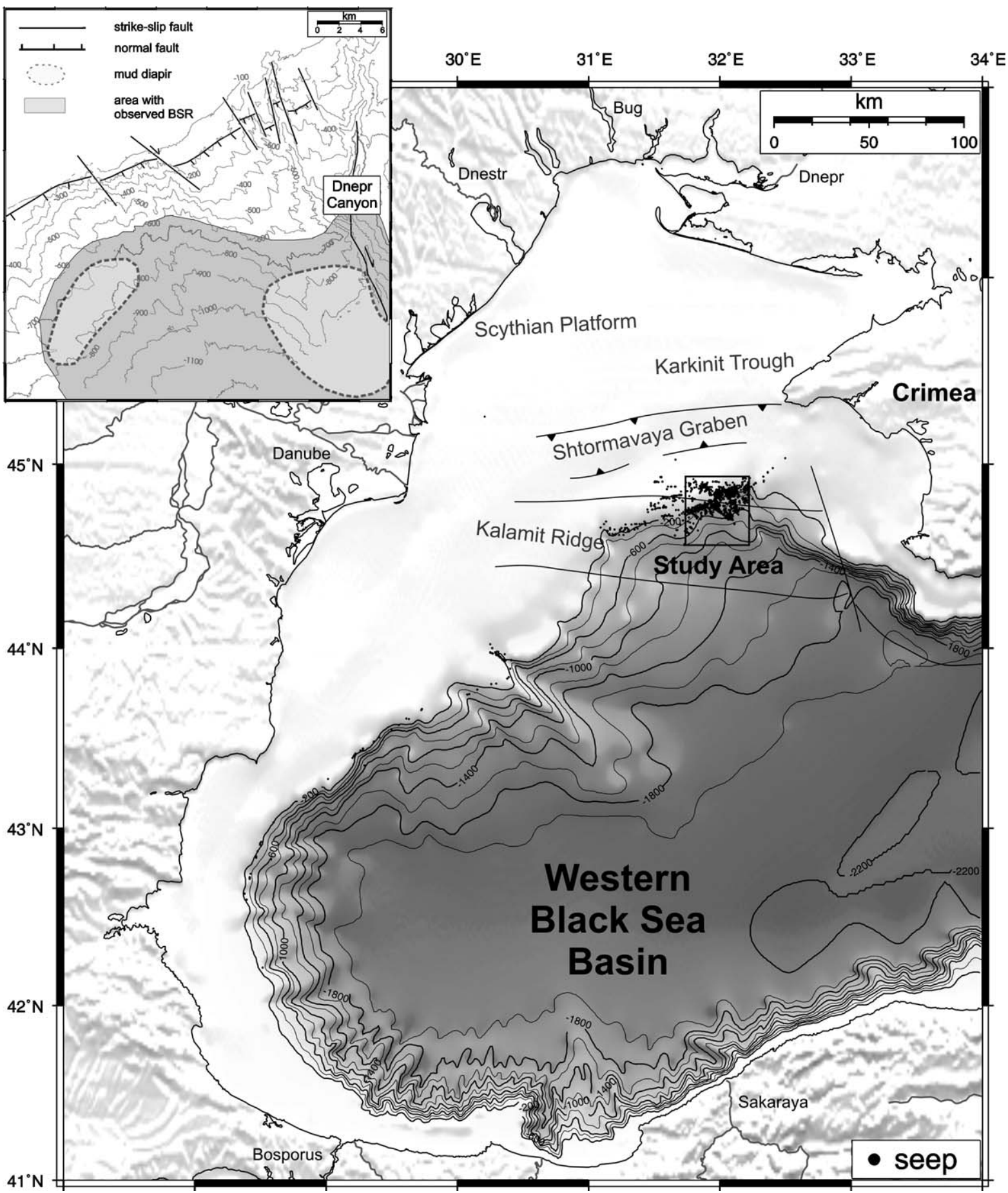

Fig. 1. Location map of the Dnepr paleo-delta study area with indication of deep structures, major faults and seep locations in the northwestern Black Sea (Robinson et al., 1996; Egorov et al., 1998). Inset shows the bathymetry of the study area in greater detail, with indication of faults, mud diapirs, area with observed BSR and the Dnepr Canyon (after Lüdmann et al., 2004).

al., 2004). Structurally, this part of the Black Sea forms the transition zone between the Scythian Platform and the Karkinit Trough in the north, the Shtormavaya
Graben, the Kalamit Ridge and the Western Black Sea Basin in the south (Robinson et al., 1996; Nikishin et al., 2003) (Fig. 1). The Western Black 
Sea Basin was formed during the late Cretaceous in a back-arc setting above the northward subducting Tethys Ocean, close to the southern margin of Eurasia (Robinson et al., 1996). The continental margin west of the Crimea Peninsula consists of Late Paleozoic to Mesozoic basement rocks covered by thick Cenozoic sediments $(>2 \mathrm{~km}$ ) (Finetti et al., 1988).

The northwestern Black Sea is dominated by a rather wide shelf $(60-200 \mathrm{~km})$ with a shelf break at 120 to $170 \mathrm{~m}$ water depth and canyon systems with large deepsea fan complexes, mainly developed during sea level lowstands (Winguth et al., 2000; Popescu et al., 2001). The main canyon systems in the western Black Sea are the Danube and Dnepr Canyons, each with their own typical morphology. The well-studied Danube Canyon (Popescu et al., 2001, 2004) differs from the Dnepr Canyon and other, smaller canyons because it indents the shelf over a distance of $26 \mathrm{~km}$ and has a unidirectional development. The Dnepr Canyon only starts from the shelf edge and deeply incises the upper slope (Wong et al., 2002). Both canyon systems are likely to have formed by sediment flows along the axial thalweg causing sediment failures along the channel margins. These sediment failures are probably also influenced by gasrelated instability and by deep faulting (Popescu et al., 2004). The deep-sea fans, related to these canyon systems, are fed by sediment input from the Danube River (Central Europe) and the Dnepr, Dnestr and Bug Rivers (Eastern Europe). At present the Dnepr, Dnestr and Bug discharge their sediment loads into a lagoonal system separated from the Black Sea by beach barriers, and only a small fraction of the suspended load reaches the sea (Winguth et al., 2000). During the last lowstand the Dnepr and Danube flowed hundreds of kilometers beyond there present mouths depositing organic-rich material and forming shelf-edge deltas at the present-day shelf break (Ryan et al., 1997). After the last sea-level lowstand water level rose, leading to fresh-water outflow from and salt-water inflow into the Black Sea through the Bosporus. As a result of density differences and the absence of complete water-column mixing, the Black Sea became the biggest anoxic basin in the world, with favorable conditions for preserving organic material and generating hydrocarbons (Jørgensen et al., 2004). A well-pronounced oxycline at about $90 \mathrm{~m}$ separates the upper oxic from the deeper, permanently sub-oxic and anoxic water masses. So it is not surprising that the shelfedge deltas and adjacent areas of the northwestern Black Sea are characterized by shallow gas and gas seeps (Polikarpov et al., 1989, 1992; Egorov et al., 1998; Popescu et al., 2004) that release methane of microbial origin (Amouroux et al., 2002; Michaelis et al., 2002).
The Dnepr paleo-delta area is the most prolific seep area of the northwestern Black Sea margin and possibly one of the most active in the World (Hornafius et al., 1999). The methane seeps in this area were first registered on echosounder recordings by Polikarpov et al. in 1989. Later studies discovered more seeps (Polikarpov et al., 1992; Egorov et al., 1998) as well as the presence of carbonate build-ups formed by anaerobically oxidized methane in an anoxic environment at $230 \mathrm{~m}$ water depth (Luth et al., 2000; Thiel et al., 2001; Peckmann et al., 2001; Michaelis et al., 2002). Gas seeps occur in the oxic as well as in the anoxic zone over a wide depth range from 35 to $785 \mathrm{~m}$ (Egorov et al., 1998). This part of the northwestern Black Sea margin is dominated by the presence of the Dnepr Canyon and the Dnepr Fan. The Dnepr Fan starts at a water depth of about $300 \mathrm{~m}$ and it consist of several vertically stacked, laterally displaced channel-levee systems, deposited during water-level lowstands. Generally, the channel floors are covered by coarse-grained deposits and flanked by finer-grained levee and overbank sediments deposited during overflow of the canyons. The area east of the Dnepr Fan is characterized by drift sedimentation, whereas to the west, mass-wasting and mass-transport deposition is prominent (Wong et al., 2002).

Southwest of the Dnepr Canyon a bottom simulating reflection (BSR) has been observed on seismic recordings between 700 and $1350 \mathrm{~m}$ water depth (inset Fig. 1) (Lüdmann et al., 2004; Zillmer et al., 2005). Commonly, a BSR is a high-amplitude reflection that runs sub-parallel to the sea-floor reflection, has a polarity that is opposite to that of the sea-floor reflection and occasionally crosscuts the sediment stratification (Kvenvolden, 1998). BSRs mark the temperature- and pressure-controlled base of the gas-hydrate stability zone (BGHSZ) and are therefore commonly regarded as an indirect indication for the presence of gas hydrates.

The seismic studies by Lüdmann et al. (2004) also revealed the presence of possible faults and mud diapirs in the Dnepr paleo-delta area (Fig. 1).

\section{Data and methods}

The data presented in this paper were gathered during the 58th (May-June 2003) and 60th (MayJune 2004) cruise of $R V$ Professor Vodyanitskiy. We combine and integrate hydro-acoustic water-column data, hydro-acoustic sea-floor data and seismic subsurface data (Fig. 2) to obtain better insight in the geological and morphological characterization of the discovered seep sites. 

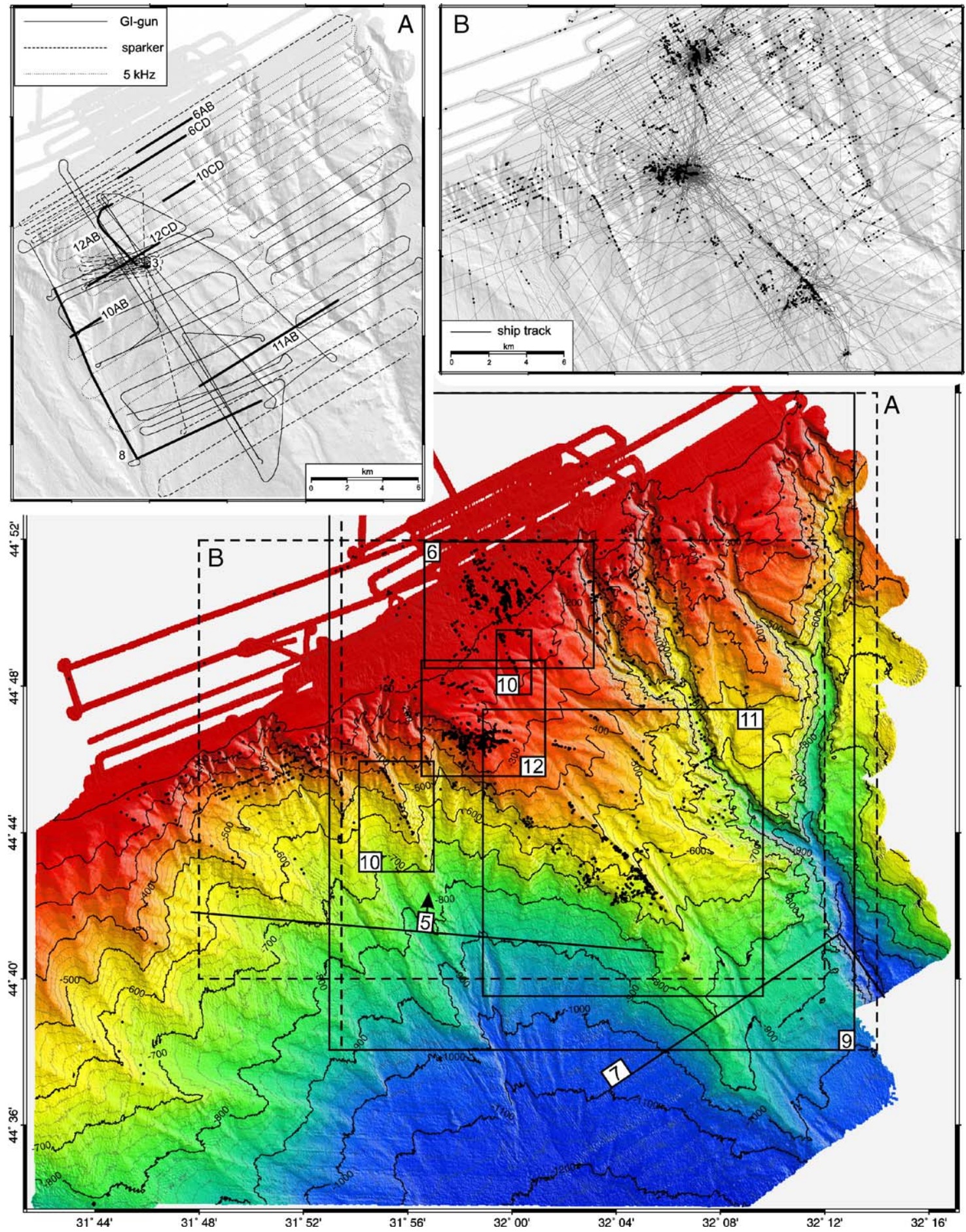

Fig. 2. Swath bathymetry map (30 m grid) acquired during the 2003 and 2004 CRIMEA cruises with all newly detected seeps plotted as black dots. Gaps in the multibeam coverage were filled in by data from the 2004 METROL cruise. The outlines of the areas covered by Figs. 6, 9-12 is indicated as well as the viewing direction of Fig. 5 and the location of the profile used in Fig. 7. Inset A shows the track lines of the seismic data (GI-gun, sparker and $5 \mathrm{kHz}$ ) acquired within the study area and the seismic and echosounder profiles shown in this manuscript are also indicated. Inset B gives an overview of the ship tracks sailed during the 2003 and 2004 CRIMEA cruises and along which hydro-acoustic seep detection was performed (seeps locations are plotted as black dots). 


\subsection{Water-column data}

Hydro-acoustic water-column data was recorded with a hull-mounted SIMRAD EK500 dual-frequency (38 and $120 \mathrm{kHz}$ ) split-beam echosounder. This system operates with a total beam width of $7^{\circ}$. Due to the high impedance contrast between water and free gas, gasbubble seepage in the water column can be acoustically detected and shows up as "acoustic flares" on echograms (Fig. 3). Such a flare can comprise one single bubble stream or can be a conjugation of different bubble streams or seeps within the footprint of the echosounder. The WaveLens software package (by Y. Artemov) was used to trace and locate the origin of the bubble streams, i.e. the exact position of the seeps at the sea floor, based on gas-bubble backscatter strength. Video footage of the sea floor, collected by OFOS (Ocean Floor Observation System), confirmed the accuracy of the seep positioning and the nearly full coverage at the major seep sites. During the two cruises, a total length of $5261 \mathrm{~km}$ echosounder tracks was recorded within the $1540 \mathrm{~km}^{2}$ study area (Fig. 2B).

\subsection{Sea-floor data}

Regional bathymetric mapping of the study area was performed with a mobile $50 \mathrm{kHz}$ swath system (SeaBeam 1050). This system operates with 126 beams (width $1.5^{\circ}$ by $3^{\circ}$ beam angle and $120^{\circ}$ swath) and it was motion-compensated by an OCTANS 3000 motion sensor. Sound-velocity profiles were acquired via CTD casts and the sound velocity at the transducers was continuously measured. Data acquisition was managed with Hydrostar Online and the data processing was carried out with HDPEdit and HDPPost. Fine editing of the data by deleting bad data points was done with Fledermaus (6.1.2), which was also used for the visualization of the merged data sets. During the two cruises, an area of $1540 \mathrm{~km}^{2}$ was covered in water depths from 57 to $1248 \mathrm{~m}$ (Fig. 2). Gaps in the multibeam coverage were filled in by data acquired during the 2004 METROL cruise (Poseidon cruise P317/3) with the same swath system (SeaBeam 1050) as used during the CRIMEA cruises. All grids shown in this paper have a cell size of $30 \mathrm{~m}$, except when specifically mentioned otherwise.

\subsection{Sub-surface data}

Three different types of seismic data were acquired (GI-gun, sparker and $5 \mathrm{kHz}$ sub-bottom profiler) (Fig. 2A), each within a different frequency range to extract the best possible information about the underlying geology.

A first set of single-channel seismic data were acquired with a GI-gun source (central frequency of $150 \mathrm{~Hz}$; maximum shooting interval of $8 \mathrm{~s}$ ) and an active surface streamer with 10 hydrophones. The

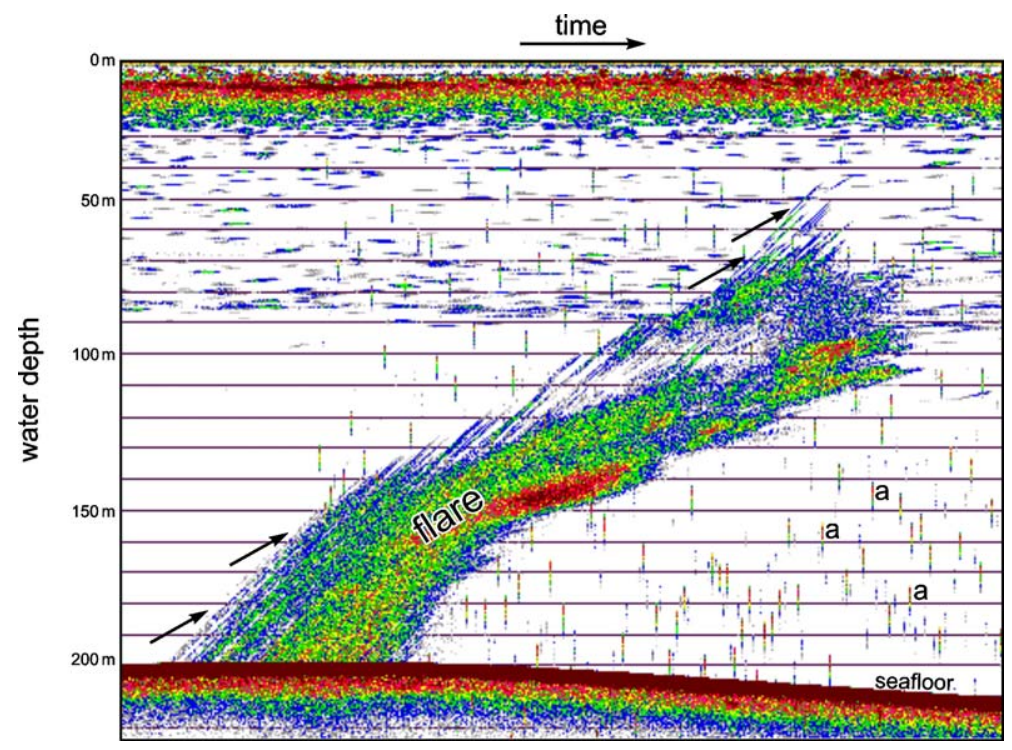

Fig. 3. Hydro-acoustic image ("flare") of several methane bubble trains rising towards the sea surface at a seep site at $200 \mathrm{~m}$ water depth. The image consists of a succession of pings over a certain time interval. The tilted arrows show the rise of isolated bubbles. The bubbles clearly cross the oxicanoxic interface at $90 \mathrm{~m}$ water depth. The other backscatter signals above this depth correspond to fish, jelly fish and larvae. The vertical acoustic anomalies (a) are caused by the parallel running multibeam system. 
raw signal was analog filtered $(70-200 \mathrm{~Hz})$ and recorded on a Delph-2 system. The theoretical vertical resolution is $6 \mathrm{~m}$ and the maximum penetration is $600 \mathrm{~ms}$ TWTT. Single-channel GI-gun data were recorded only during the first cruise and this over a total length of $664 \mathrm{~km}$.

A second set of single-channel seismic data were collected with a SIG sparker source (central frequency of $500-700 \mathrm{~Hz}$ ) and an active surface streamer with 10 hydrophones. The analog signal was bandpass-filtered (200-2000 Hz) and recorded on a Delph-2 system. The theoretical vertical resolution is $1 \mathrm{~m}$ and the maximum penetration is $100 \mathrm{~ms}$ TWTT. During the 2003 cruise, 332 $\mathrm{km}$ of sparker data were recorded.

Sub-bottom profiling data were shot with a $5 \mathrm{kHz}$ profiler system (Sonic-3), which was mounted in a tow fish with a fish-track underwater-navigation system and a pressure sensor. The tow fish was towed 100-200 m above the sea floor. The theoretical vertical resolution is $30 \mathrm{~cm}$ and the maximum penetration is $35 \mathrm{~ms}$ TWTT. During the 2003 cruise, $589 \mathrm{~km}$ of $5 \mathrm{kHz}$ data were recorded.

Apart from the frequency filtering no other processing was carried out on the seismic data. Interpretation of the data was carried out with the Kingdom Suite software package.

The multi-channel GI-gun profile shown in Fig. 7 was recorded during the 2001 GHOSTDABS cruise and was made available by the Institute of Biogeochemistry and Marine Chemistry of the University of Hamburg. The profile was published before by Lüdmann et al. (2004).

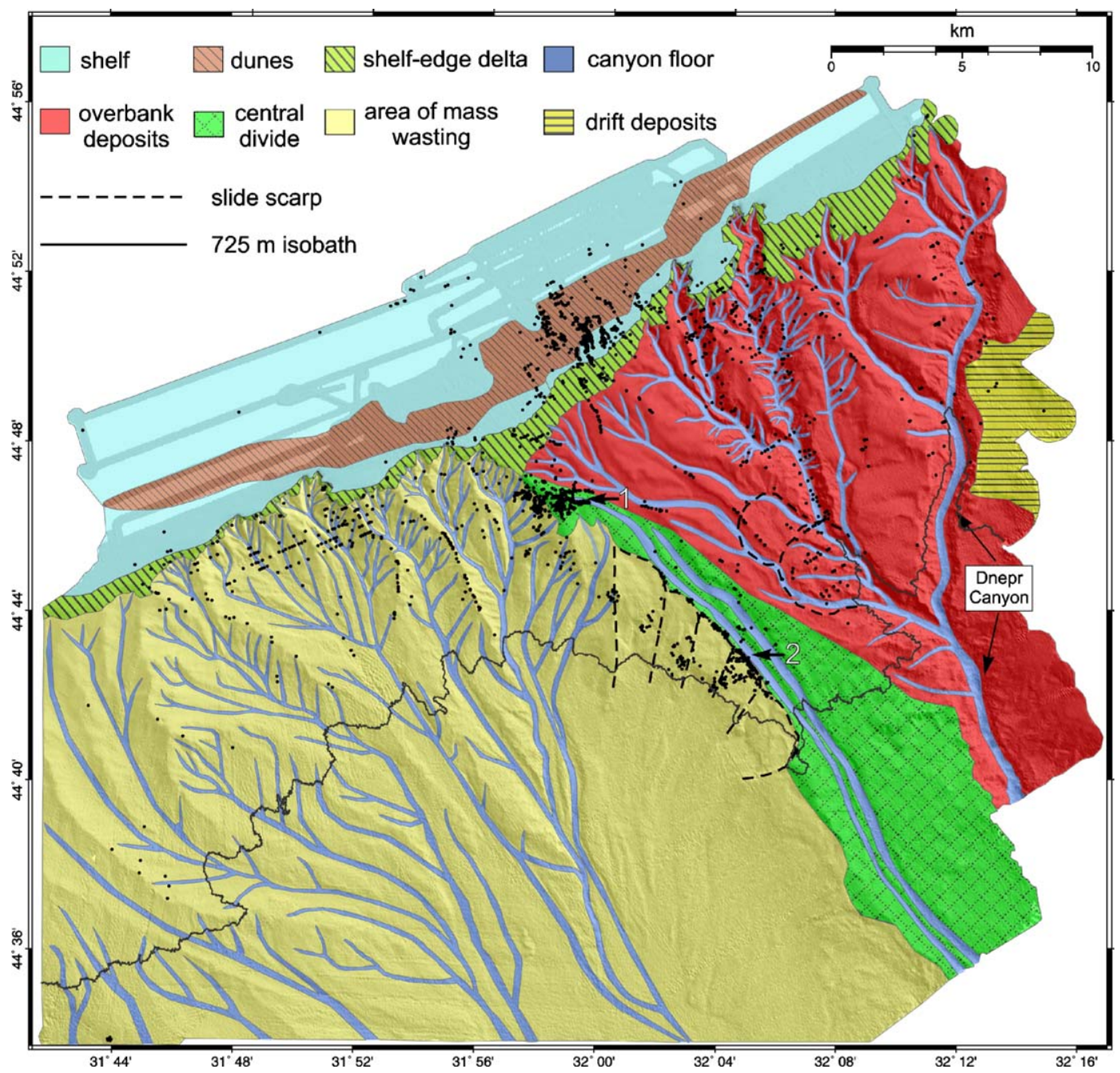

Fig. 4. Map of the study area with indication of the major geomorphological regions and canyons. Seep locations are plotted as black dots. The scarps of the submarine landslides are emphasized by dashed lines and the position of two chimney fields is indicated by 2 horizontal arrows (1: Michaelis et al., 2002; 2: CRIMEA cruise 2004). 


\section{Observations and results}

\subsection{Morphology}

The Dnepr paleo-delta study area covers the transition zone between the continental shelf and the continental slope. The water depth in the study area ranges from 57 to $1248 \mathrm{~m}$ and the shelf break occurs at $125 \mathrm{~m}$ water depth (Fig. 2).

\subsubsection{Shelf}

The shelf is characterized by a flat, sub-horizontal surface (Figs. 2, 4 and 5) with a maximum slope of $0.5^{\circ}$. Close to the shelf break, this flat surface is locally interrupted by a dune field (Figs. 4 and 6). The majority of the dunes have a NW-SE orientation, a wave length of $120 \mathrm{~m}$ and a height of 1.5-2.5 m. Most of the dunes are symmetrical, but at the SW and NE borders of the central dune field, they are barchanoid in shape. South of the dune field, four elongated depressions occur. They have a maximum length of $500 \mathrm{~m}$, a maximum width of $100 \mathrm{~m}$ and a maximum depth of $3 \mathrm{~m}$. They appear to be an amalgamation of smaller depressions (Fig. 6).

\subsubsection{Slope}

The slope can be sub-divided in two morphologically contrasting segments: a western area dominated by mass-wasting and an eastern area dominated by deposition. These two areas are separated by a clear boundary, which we will hereafter refer to as the "central divide" (Figs. 4, 5 and 11).

\subsubsection{Western mass-wasting dominated area. In the} western area, the morphology is dominated by a canyon system with sedimentary ridges and gullied walls (Figs. 4 and 5). Some of the canyons incise the shelf up to a water depth of $100 \mathrm{~m}$ and indent the shelf edge over a maximum distance of $2 \mathrm{~km}$. The canyons have cauliflower-shaped heads and are bifurcated in the central part (Fig. 4). The canyons at the western side of the area are more elongated and less bifurcated. At the eastern side, adjacent to the central divide, canyons are absent and five submarine landslides can be identified (Figs. 4, 5 and 11). The maximum size of one individual slide is 3 by $5 \mathrm{~km}$. The submarine landslides cover an area of $38 \mathrm{~km}^{2}$ in water depths from 355 to $975 \mathrm{~m}$. The head scarps have a maximum height of $45 \mathrm{~m}$ and form slopes of $10^{\circ}$ to $20^{\circ}$. Within the slide areas, several smaller scarps are visible (Fig. 5), indicating multiple failure

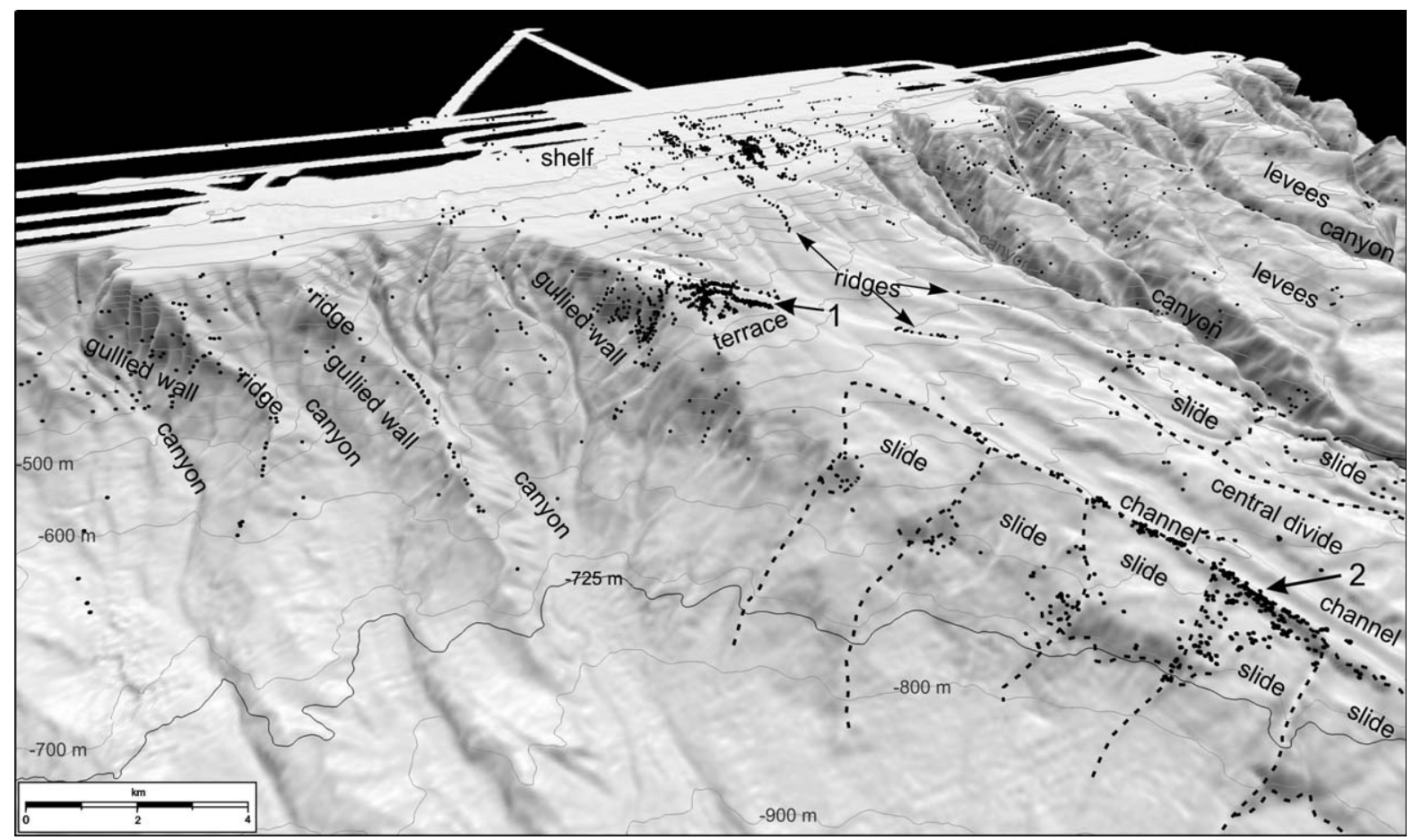

Fig. 5. Oblique view of grey-shaded bathymetry map of the upper part of the study area with indication of different geomorphological features (see Fig. 2 for location). Seeps locations are plotted as black dots. The scarps of the submarine landslides are emphasized by dashed lines and the position of the 2 chimney fields is indicated by 2 arrows (1: Michaelis et al., 2002; 2: CRIMEA cruise 2004). Seep clusters are evident at the crest of sedimentary ridges, at submarine landslides, along canyons, on the shelf and at the terrace at $200 \mathrm{~m}$ water depth. 

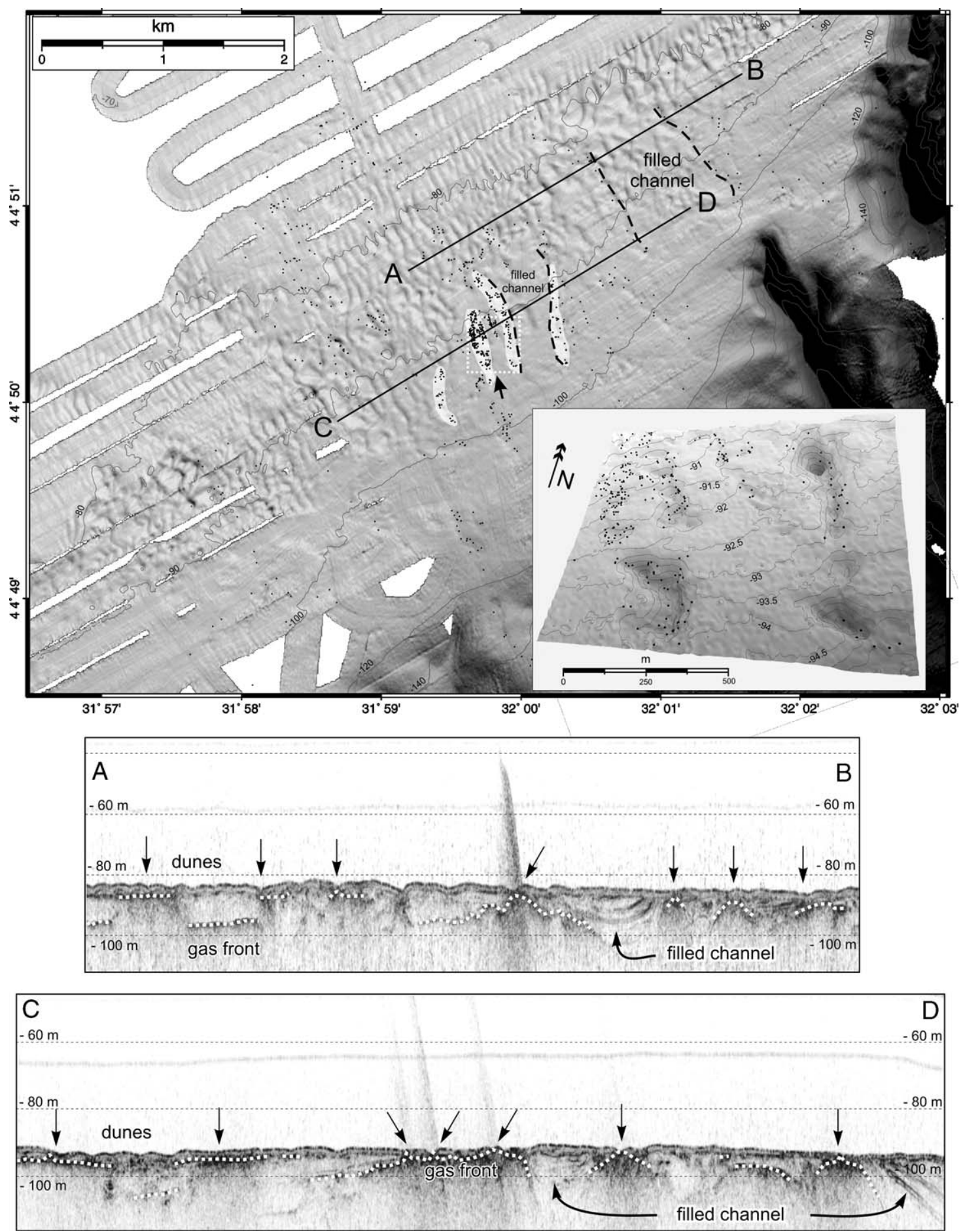

Fig. 6. Plan view of grey-shaded bathymetry map of the shelf and the dune area ( $5 \mathrm{~m}$ grid) overlain by bathymetric contours (see Fig. 2 for location). The four elongated depressions are marked by a transparent white mask. The inset shows an oblique view of the intensive seep site at $92 \mathrm{~m}$ water depth characterized by pockmarks. Seep positions are plotted as black dots. On the $5 \mathrm{kHz}$ profiles AB and CD (see Fig. $2 \mathrm{~A}$ for location) the updoming gas front (dotted white line) underneath the seep positions (arrows) is clearly visible. Seeps are located at the margins of filled channels and not above them. 
events. Some remains of the slide deposits can be recognized, but most of the destabilized sediments have been eroded or transported out of the study area. Post-slide erosion is also evident from the smoothed morphology of the head scarps.

\subsubsection{Eastern deposition-dominated area. The} eastern area is dominated by deposition, with channel-levee outbuilding and deeply incised U-shaped canyons (Figs. 4 and 5). The canyons have a maximum width of $2.5 \mathrm{~km}$ and a depth of $200 \mathrm{~m}$. Similar to the erosional region in the west, the canyons incise the shelf to a water depth of $100 \mathrm{~m}$, but here they indent the shelf over a maximum distance of $4 \mathrm{~km}$. The main canyon is the Dnepr Canyon (Fig. 4) with all other canyons being tributaries to it and merging with the main tributary at $940 \mathrm{~m}$ water depth. Northwest of this confluence, opposite of the submarine landslides on the western side of the central divide, a large, double submarine landslide covers an area of $21.5 \mathrm{~km}^{2}$ between 444 and $865 \mathrm{~m}$ water depth (Figs. 4, 5 and 11). The crown scarp has a maximum height of $60 \mathrm{~m}$. In contrast with the western submarine landslides, the slide deposits in the canyon at the base of the slide are still clearly visible in the morphology and unaffected by erosion (Fig. 11).
4.1.2.3. Central divide. The eastern and western areas are separated by the central divide (Figs. 4, 5 and 11). Within the central divide two parallel channels extend over a length of more than $24 \mathrm{~km}$, with a maximum depth of $45 \mathrm{~m}$ and a mutual width of $1.5 \mathrm{~km}$. Apart from these two parallel depressions, there are no other major channels incising the divide. Upslope, the central divide ends at a terrace-like feature at 180 to $230 \mathrm{~m}$ water depth, which forms the transition to the shelf.

Fig. 7 indicates that the rather unusual morphology of the central divide has been inherited from a series of underlying, buried channel-levee systems. The two parallel channels within the central divide are formed probably due to differential compaction of the underlying channel sediments, which resulted in the two channels with central ridge morphology.

\subsection{Seep locations}

Up to 2778 methane seeps were hydro-acoustically detected in an area of $1540 \mathrm{~km}^{2}$, in water depths ranging from 66 to $825 \mathrm{~m}$. Of all detected seeps, $99.5 \%$ are located in water depths shallower than $725 \mathrm{~m}$ (Figs. 2 and 4) where they are clustered in certain morphological locations (Fig. 5).

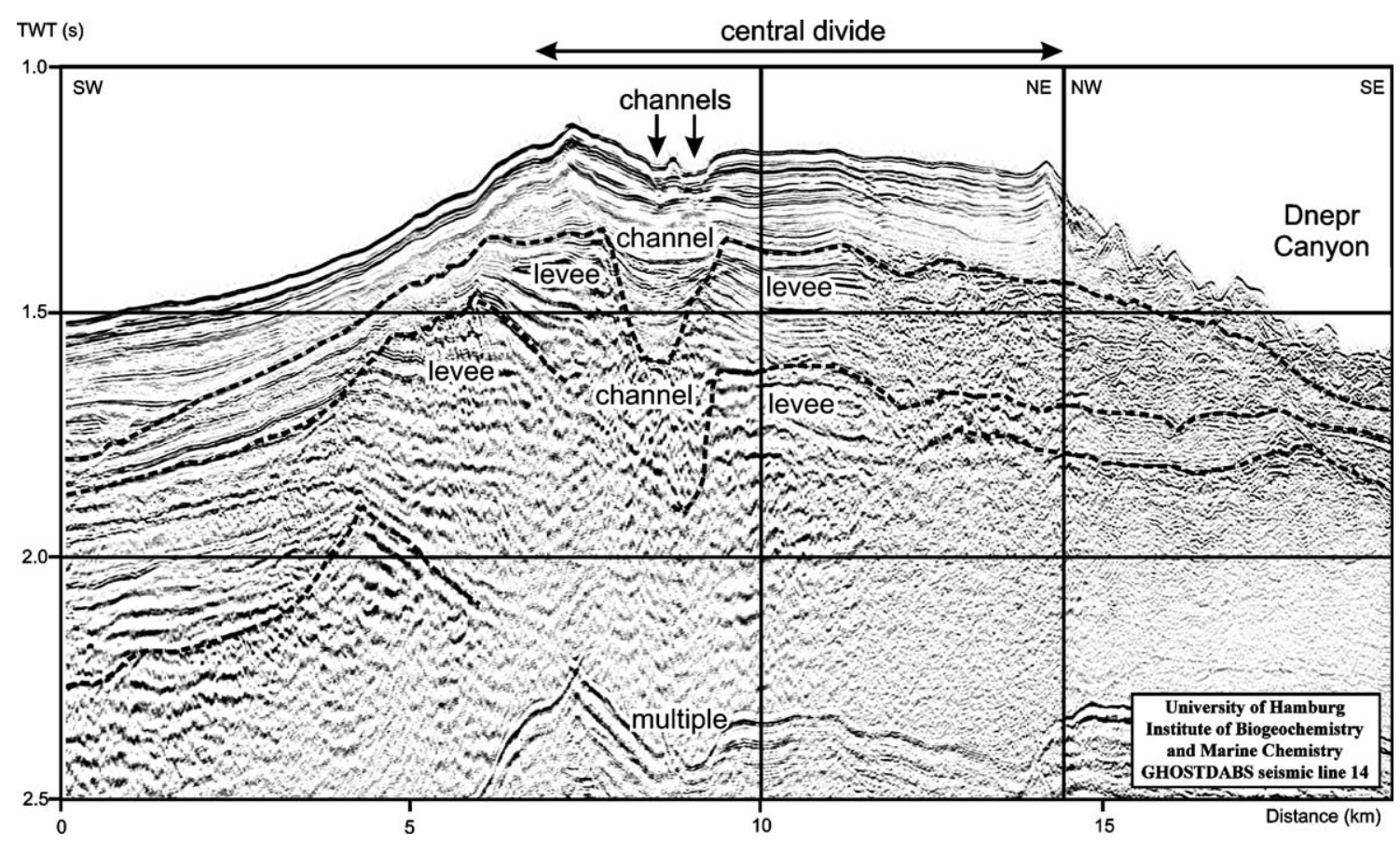

Fig. 7. A multi-channel GI-gun profile (see Fig. 2 for location) from the GHOSTDABS project (Lüdmann et al., 2004) clearly indicates that the rather unusual morphology of the central divide has been inherited from a series of underlying, buried channel-levee systems. The two parallel channels within the central divide are formed probably due to differential compaction of the underlying channel sediments, which resulted in the two channels with central ridge morphology. Also notice the presence of the Dnepr Canyon. 
Seeps on the shelf are concentrated in the dune field and are especially abundant in the elongated depressions to the south of the dune field. Because of the clear relationship between the seeps and the elongated depression, we interpret these depressions as pockmarks (Hovland and Judd, 1988). On the shelf, the seeps appear to be following a general NW-SE trend (Fig. 6). This orientation is perpendicular to the majority of the ship tracks (Fig. 2B), which indicates that it is natural and does not originate from data acquisition.

On the slope there are several places and structures which are bound to seepage.

In the mass-wasting dominated region, the majority of the seeps occur on crests of sedimentary ridges, on gullied canyon walls or on the scarps of submarine landslides (Figs. 2, 4 and 5). On one of the scarps a new carbonate chimney field was discovered during the 2004 CRIMEA cruise by visual observations and dredge sampling in about $600 \mathrm{~m}$ water depth (Figs. 4 and 5).

In the deposition-dominated area, seeps are linked to canyons: either on the bottom, or on the flanks or margins. Some seeps are located on the crests of sedimentary ridges (Fig. 5). The scarps of the submarine landslides in this area are not characterized by seep occurrences like in the western area, but seeps are present within the double submarine landslide (Figs. 4 and 5).

On the central divide, seeps are in general rather scarce (Fig. 4). In contrast, they are abundant on the terrace at 180-230 m water depth (Fig. 5). The terrace actually consists of three radially spread ridges within the lobed morphology of the terrace (Fig. 2). The carbonate chimney field, described earlier by Michaelis et al. (2002), is located on the crest of one of these ridges (Figs. 4 and 5).

\subsection{Gas hydrate and free gas occurrences}

As mentioned above, the vast majority of the gas seeps occur in water depths from 66 to $725 \mathrm{~m}$, and only a dozen seeps were detected below $725 \mathrm{~m}$ water depth (Figs. 2 and 4). Some of these 'deep-water' seeps are located at $825 \mathrm{~m}$ water depth, above a sub-surface mud-volcano-like structure described by Kruglyakova et al. (2004). The other 'deep-water' seeps are located close to the $725 \mathrm{~m}$ contour line. The almost complete absence of seeps below $725 \mathrm{~m}$ water depth strongly suggests that no free gas is present, at the sea floor, below this depth.

The stability limit of pure methane hydrates occurs at $725 \mathrm{~m}$ water depth (Sloan, 1990), when calculated using a present-day bottom-water temperature of $8.9{ }^{\circ} \mathrm{C}$ (CRIMEA cruises) and a presumed average open-ocean pore-water salinity in the sedimentary column of 35 ppt. The presence of gas hydrates in the area had already been indicated by the observation of a BSR (Lüdmann et al., 2004; Popescu and De Batist, 2004; Zillmer et al., 2005) and confirmed by direct sampling (Kruglyakova et al., 2004). Zillmer et al. (2005) determined for the study area, that there is $38 \pm 10 \%$ hydrate in the pore space at BSR depth, where the porosity is $57 \%$. Our GI-gun data also demonstrate a BSR-like event that is located at the calculated sub-bottom depth of the BGHSZ (Fig. 8). It displays a number of characteristics of a typical BSR (i.e. low amplitudes above, enhanced reflections below, cross-cutting the stratigraphy), but instead of appearing as a distinct, single reflection, the BGHSZ on our data is expressed as a transition from highamplitude (gas-enhanced) reflections below and lowamplitude (blanked) reflections above (Fig. 8). Such seismic response is attributed to the relatively high frequency of the seismic signal and to the acquisition lay-out with relatively short offsets (Vanneste et al., 2001).

The BGHSZ reflection approaches the sea floor close to $725 \mathrm{~m}$ water depth. From that point on, bubbles are detected in the water column (Fig. 8, graph). Low reflection amplitudes within the GHSZ are often attributed to the presence of gas hydrates in the sediment pore spaces (Lee and Dillon, 2001), although this could not be confirmed in e.g. the Blake Ridge hydrate area (Holbrook, 2001). The presence of free gas below the hydrate-cemented strata is indicated by enhanced reflections below the low-amplitude zone. Since the enhanced reflections are present on our seismic records both in the "hydrate zone" and in the "no-hydrate zone", we interpret the top of the enhanced reflections as the "gas front", i.e. the upper boundary of the sediment package containing free gas (Fig. 8). However, it has to be taken into consideration that the physical processes controlling the depth of the free gas in both areas are different, but also that the acoustic expression of the top of the free-gas section as gas front is dependent on the frequency of the seismic signal.

Free gas can easily be identified on seismic recordings (e.g. acoustic turbidity, enhanced reflections, acoustic blanking, etc.) because of its influence on the sediment's bulk properties (Judd and Hovland, 1992; Anderson and Hampton, 1980). The exact response to the presence of free gas depends on the frequency of the seismic source (Richardson and 


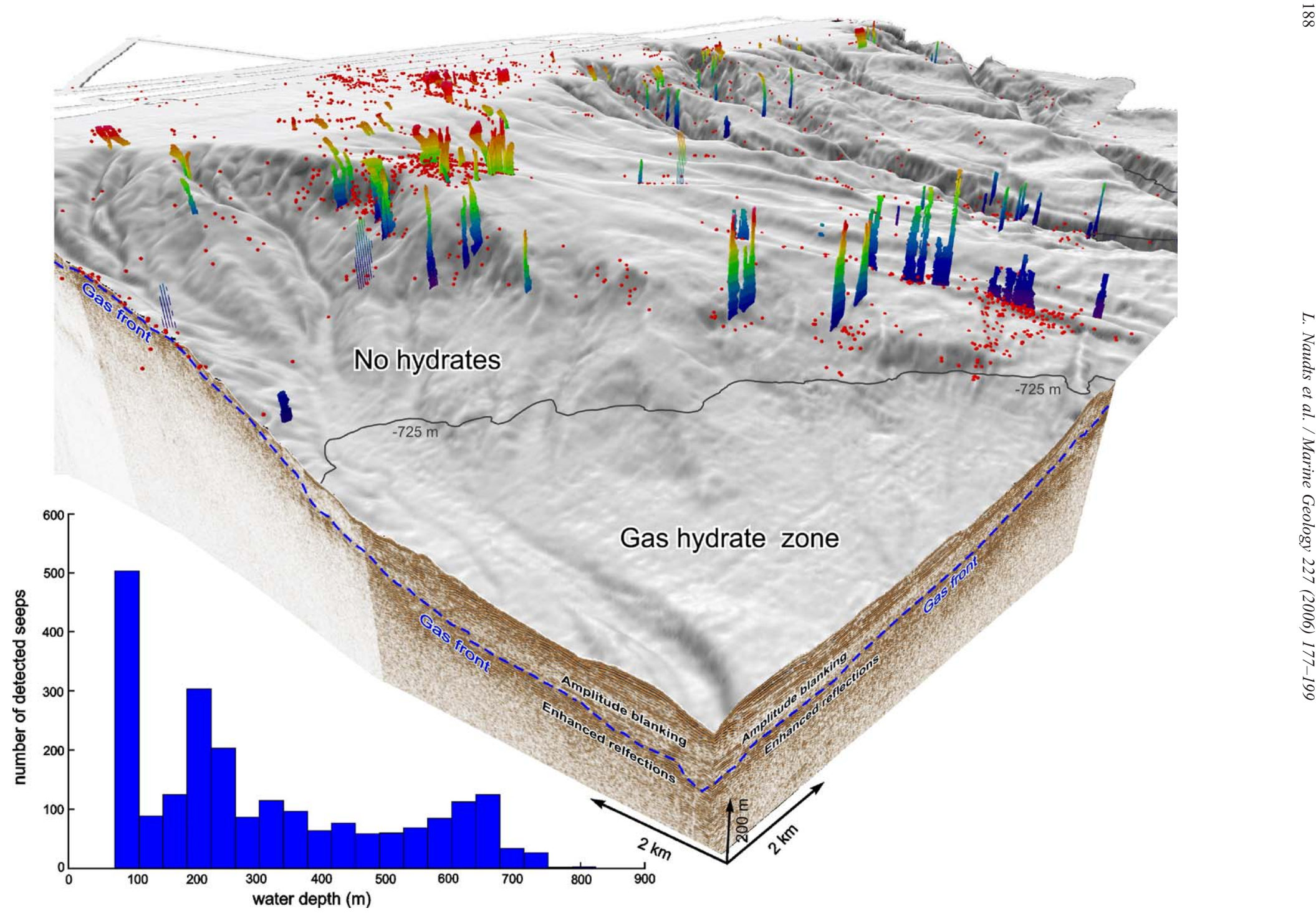

Fig. 8. Oblique view of grey-shaded bathymetry map (see Fig. 2A for location), seep locations plotted as red dots and some seeps are shown as 3D flares. Seeps are abundant upslope of the GHSZ, delineated by the $-725 \mathrm{~m}$ contour line. The two crossing GI-gun profiles clearly show that the gas front, i.e. the top of the free gas in the sub-surface as indicated by the enhanced reflections, domes up to the surface outside the GHSZ, where gas bubbles were detected in the water column. The graph in the lower left corner shows the seep distribution versus depth with clear seep clusters at 92,200 and at $650 \mathrm{~m}$ water depth, just outside the GHSZ. 
Davis, 1998). The $5 \mathrm{kHz}$ sub-bottom data provide the best coverage in the study area (Fig. 2A) and are best suited for mapping the gas front because of the stronger attenuation of the higher frequencies. On these data the gas front is expressed as the upper termination of a series of enhanced reflections or as a highamplitude reflection that cross-cuts the normal stratigraphy and that completely masks all reflections below (Figs. 6, 10-12). Based on these criteria, the depth of the top of the free gas zone in the sediment can be mapped throughout the area.

The $5 \mathrm{kHz}$ seismic data show that the depth of the gas front is variable and locally domes up to the sea floor (Figs. 6, 10-12). The areas of gas-front updoming coincide with seep locations as observed by hydro-acoustics. By combining the gas-front surface with the seafloor surface, a "depth-to-gas-front" map was produced (Fig. 9), which illustrates the strong "gas front-versusseep" relationship that was already observed on the seismic profiles. The majority of the seeps occur where the gas front approaches the sea floor within $<25 \mathrm{~m}$, and in most cases even within $<10 \mathrm{~m}$ (Fig. 9).

\subsection{Seep relation to morphology and sub-surface structure}

\subsubsection{Continental shelf}

The highest concentrations of seeps on the shelf are found within the elongated depressions/pockmarks below which the updoming gas front approaches the sea floor within $<1 \mathrm{~m}$ (Fig. 6, profile CD). There are more seeps in the shallow pockmarks than in the deeper ones.

The distribution of the seeps and the general NWSE trend of the elongated depressions and of the seeps on the shelf (Figs. 6 and 9B) appears to be related to the underlying geology. On the $5 \mathrm{kHz}$ seismic profiles, seeps occur along the margins of filled channels and in association with cut-and-fill delta deposits, while no seeps have been detected above the central part of the filled channels (Fig. 6). Unfortunately, due to the attenuation of the acoustic signal, it is impossible to adequately map sub-surface geological features below the gas front.

The seeps within the dune area are also linked to an updoming gas front, but they are more randomly spread and not really linked to the particular dune morphology.

\subsubsection{Continental slope}

Within the western mass-wasting dominated environment, the seeps are preferentially located along crests of sedimentary ridges (Fig. 5). This alignment is striking and suggests a direct genetic relationship. The seismic data provide no evidence for the existence of faults which could act as conduits for upward fluid migration. However, the $5 \mathrm{kHz}$ sub-bottom data reveal a clear updoming of the gas front below the crests (Fig. 10). Also, the upper limit of the gas front is determined by a parallel-stratified sedimentary cover, which gets thinner and pinches out towards the crests of the ridges (Fig. 10).

High seep concentrations also occur within the canyons and particularly on the gullied canyon walls (Figs. 5 and 12). These canyon walls are strongly affected by mass wasting. Seeps are predominant on the steep, freshly scarred gullied walls, but not on older smoothed canyon walls. The sub-surface data shows that mass wasting at the gullied walls breaches the sedimentary cover and creates fresh scars that cut off the underlying stratigraphy. At these locations, an updoming gas front is visible and gas bubbles were detected in the water column (Fig. 12, profile CD). No faults were observed below these seep locations.

A third important seep environment is formed by the scarps of the submarine landslides on the border with the central divide (Figs. 5 and 11). The water-column, bathymetric and sub-surface data show similar features as mentioned for the gullied canyon walls: scars breaching through the sediment cover and exposing underlying stratigraphy, updoming gas front and higher seep densities at fresh scars (Fig. 11, profile AB). In contrast, the scale of the submarine landslides is much bigger and the seep distribution and the scarps are lineated and not random as at the gullied walls. The seismic records do not show the presence of faults beneath these seeps locations, but this could also be due to acoustic attenuation. On other places where small sedimentary faults are present, these faults do not reach the surface and no bubbles were detected in the water column. GI-gun data (Fig. 8) show that the gas front comes up to the surface in front of the submarine landslides at $725 \mathrm{~m}$ water depth (Figs. 5 and 11), suggesting that the mass-wasting process might have been related to gas-hydrate destabilization.

To the east, in the deposition-dominated area, the same crest-seep relationship exists: i.e. no faults below seep locations, updoming gas front below the crests, parallel-stratified cover that thins out towards the crests (Figs. 10-12). One exception is that the ridges are not characterized by deeply incised canyons at the sides (Fig. 10). Also for the canyon walls we observe the same relationship between the seeps and morphological and sub-surface features: i.e. incised canyon walls, scars breaching trough sediment cover and cutting off original stratigraphy, updoming gas front and higher 
seep densities at fresh scars and at steeper canyon walls. The seismic data also reveal that the margins of the canyons are commonly covered by parallel-stratified deposits which thin out to the side of the canyons where seeps are also commonly located. Again, no major faults are observed within or near the canyons,

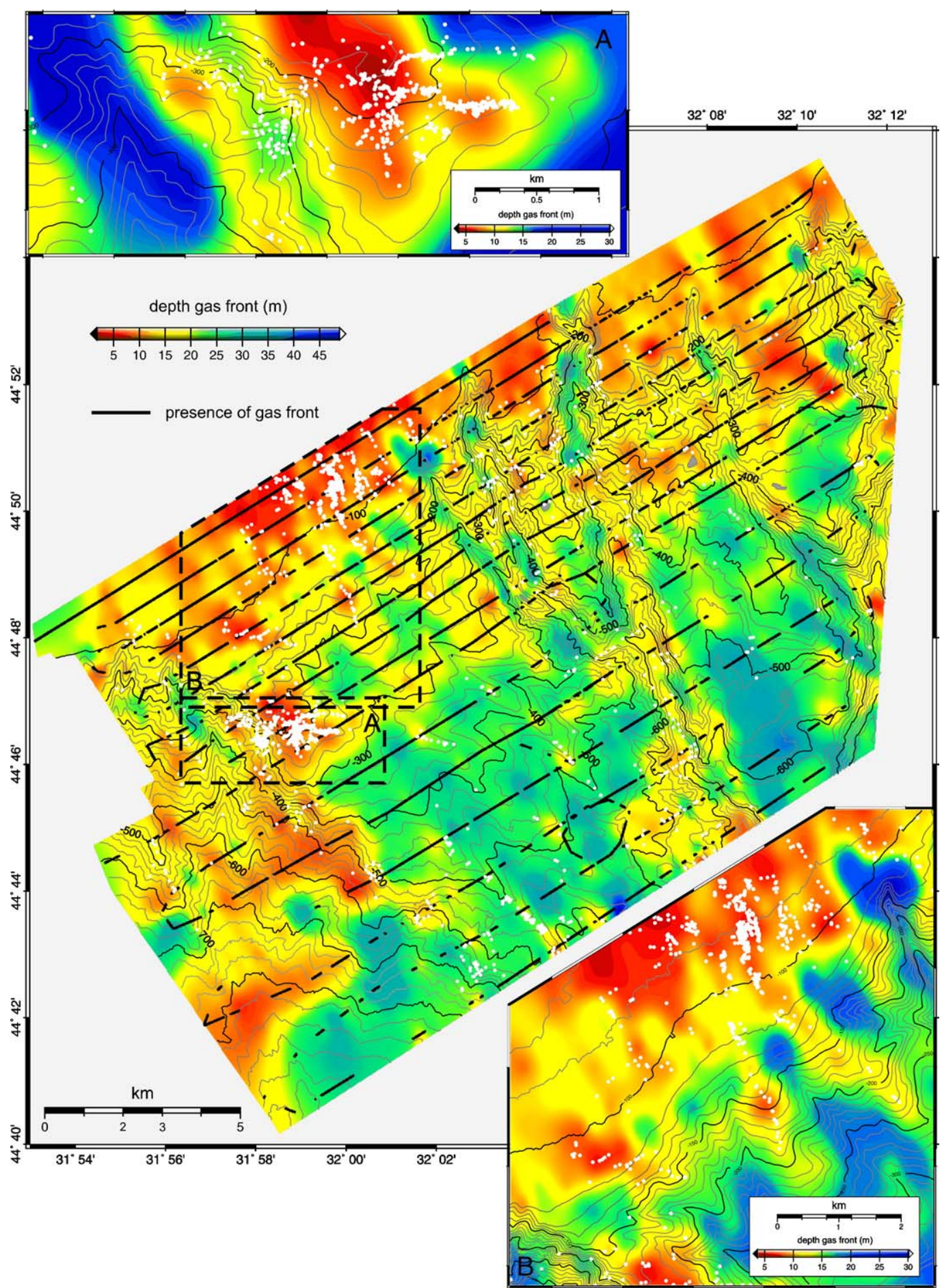

Fig. 9. Map showing the depth of the gas front beneath the sea floor (see Fig. 2 for location), as mapped on 5 kHz profiles, overlain by bathymetric contours. The map emphasizes that gas seeps (white dots) are present where the gas front approaches the sea floor. Bubbles were detected where the gas front comes within $25 \mathrm{~m}$ of the surface. For the abundant seeps sites at the terrace (inset A) and the shelf (inset B) this is $<10 \mathrm{~m}$. 


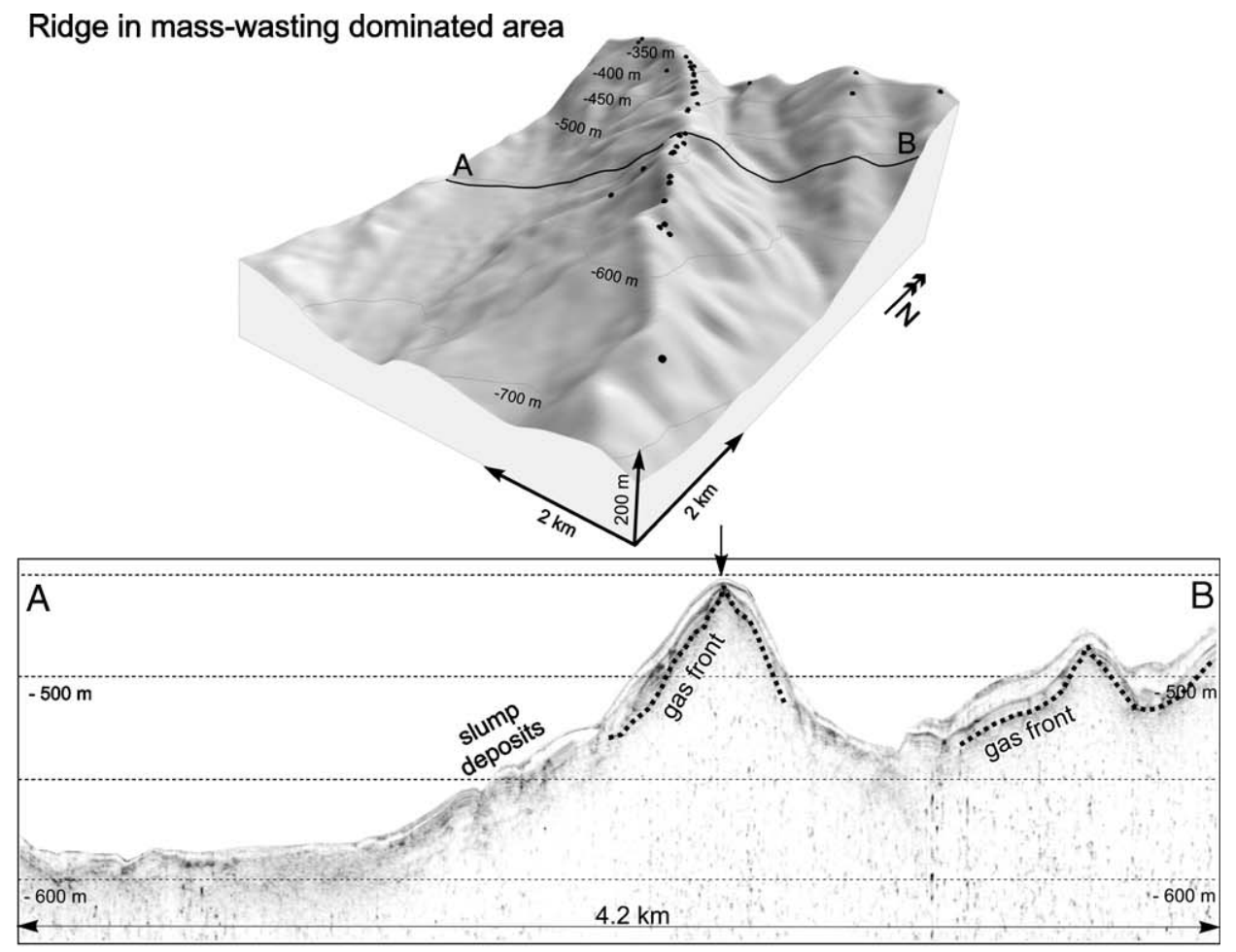

\section{Ridge in the deposition-dominated area}

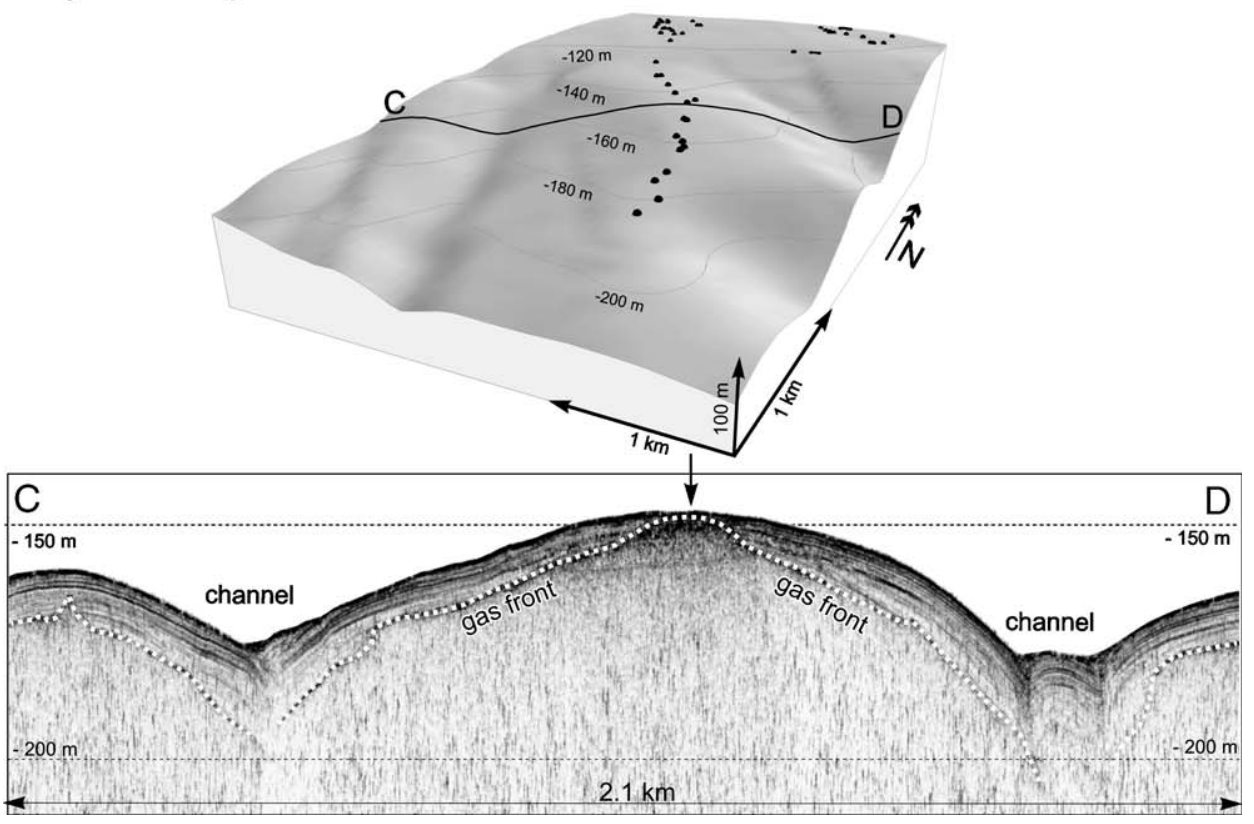

Fig. 10. Oblique view of grey-shaded bathymetry map of a sediment ridge in the mass-wasting dominated area and of a sediment ridge in the deposition-dominated area overlain by bathymetric contours (see Fig. 2 for location). Both ridges are characterized by seeps (black dots) along their crests. The $5 \mathrm{kHz}$ profiles (see Fig. 2A for location) crossing the ridges show that at both ridges the gas front domes up to the crest of the ridges where seeps (arrows) were detected and that the sediment cover thins out towards the crest. The gas front (dotted lines) follows the base of the sediment cover. 
except for a fault in the Dnepr Canyon. Our data hereby contradict those of Lüdmann et al. (2004), who observed several faults to the sides of the main canyons by using deeper-penetrating multi-channel seismic data (Fig. 1). Because of the higher frequency of our data, we were able to observe small sedimentary faults affecting the overbank deposits, but no seeps were detected above these faults.
For the submarine landslide (Fig. 11), we observed similarities with the submarine landslides in the masswasting dominated area: i.e. borders the central high, GHSZ at the base of the submarine landslide, no clear faults, updoming gas front below seep locations. However, in contrast to the submarine landslides to the west of the central divide, no seeps are present on the head scarp, which is also more circular than the linear scarps
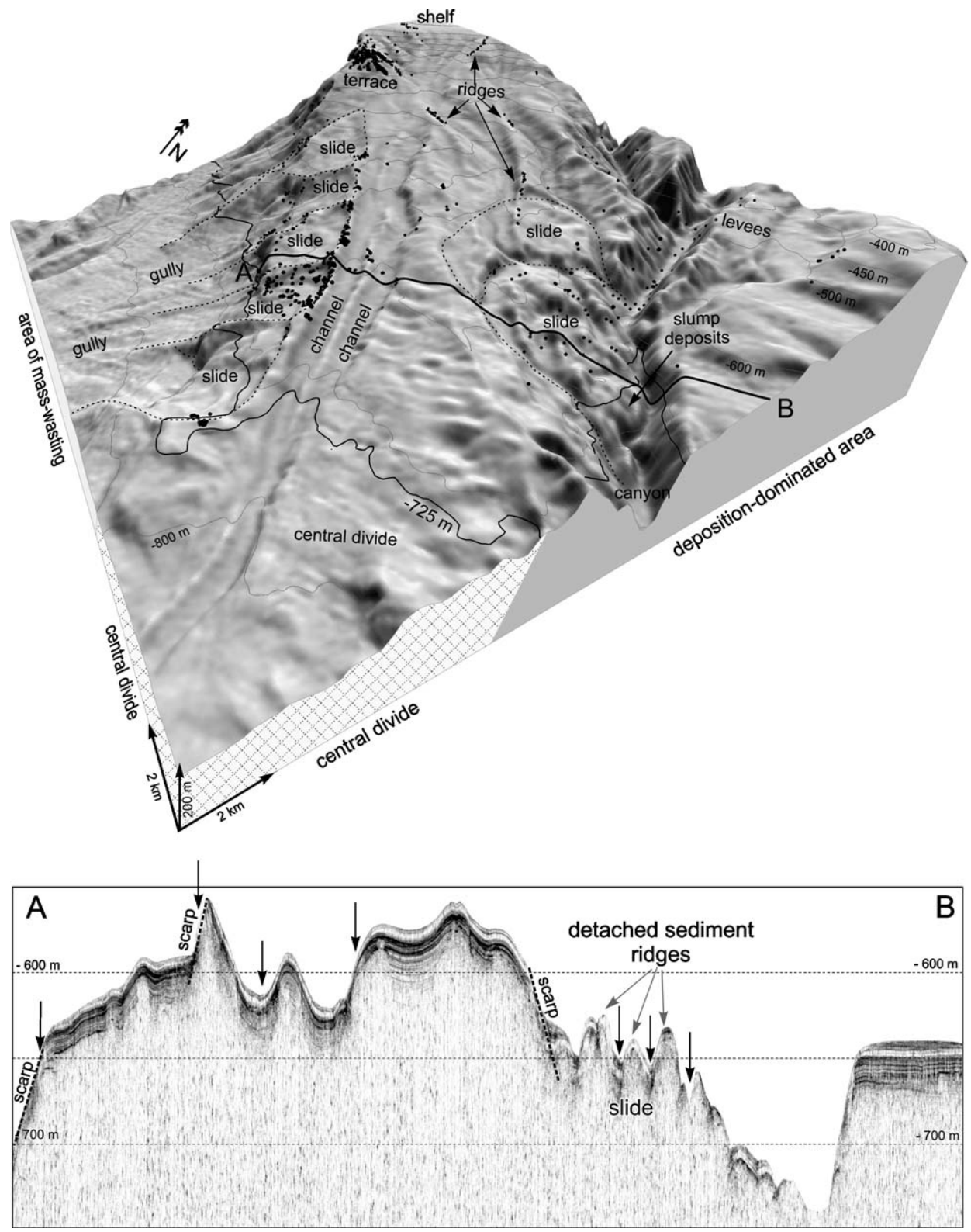

Fig. 11. Oblique view of grey-shaded bathymetry map of the area affected by submarine landslides (see Fig. 2 for location) with indication for the major geomorphological regions, overlain by bathymetric contours. The $5 \mathrm{kHz}$ profile (see Fig. 2A for location) and the 3D image show the difference in location of seeps (black dots or arrows) on scarps of the submarine landslides in the western mass-wasting area and seeps within the submarine landslides in front of detached sediment ridges in the eastern deposition-dominated area. The $725 \mathrm{~m}$ water depth contour line, marking the border of the GHSZ, is located at the base of both submarine landslide areas. 

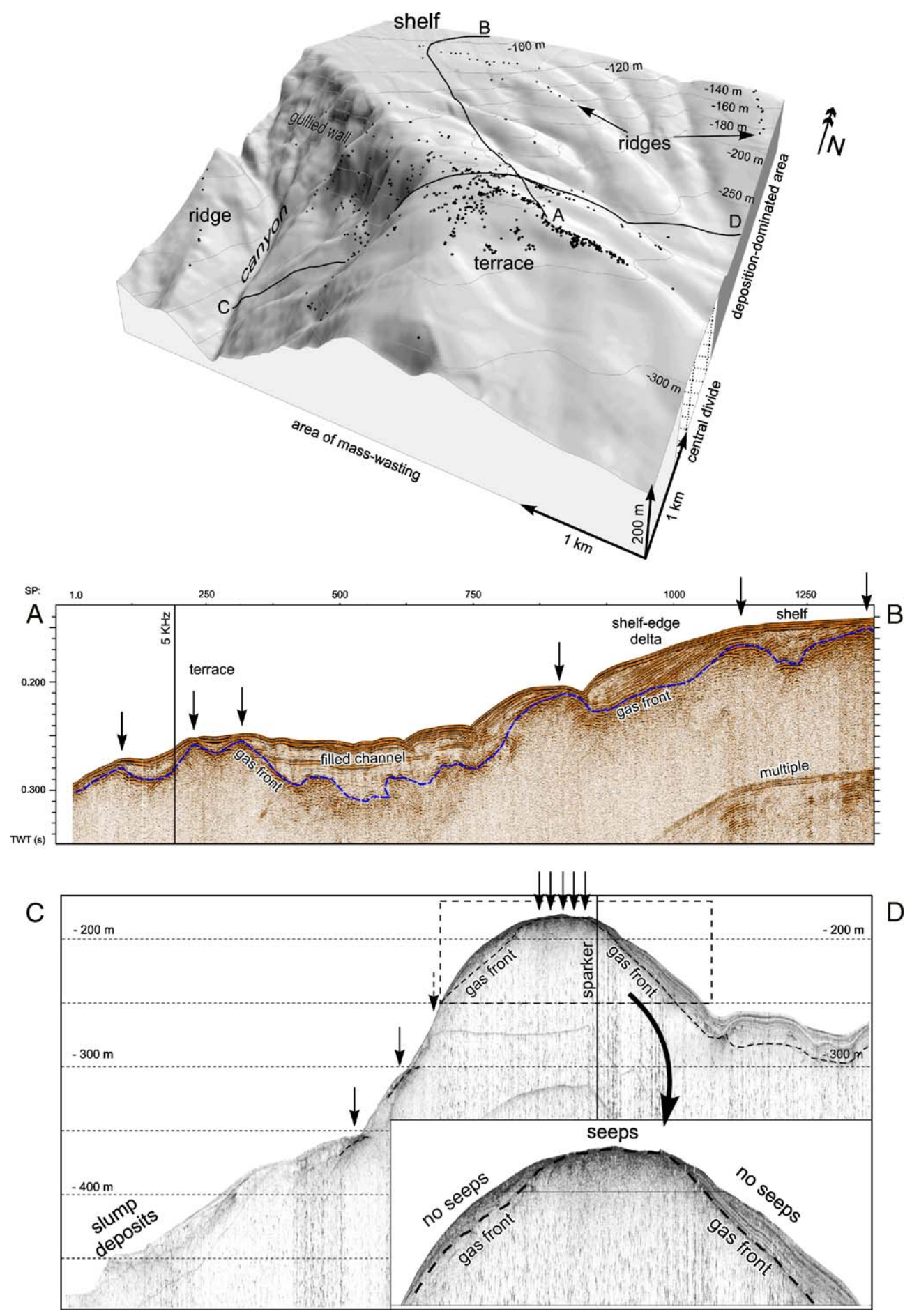

Fig. 12. Oblique view of grey-shaded bathymetry map of the terrace seep site (see Fig. 2 for location), with indication the major geomorphological regions, overlain by bathymetric contours. The sparker profile $\mathrm{AB}$ (see Fig. 2A for location) shows that seeps (black dots or arrows) are detected where the gas front domes up to the sea floor and that no gas seeps are detected above a filled channel. The perpendicular $5 \mathrm{kHz}$ (see Fig. $2 \mathrm{~A}$ for location) profile shows the same gas front-seep relation. The inset clearly shows that the gas front can only dome up to the surface where the sediment cover diminishes or is breached by mass-wasting at the flanks. During the 2004 METROL cruise this $5 \mathrm{kHz}$ profile was used as a base for coring. Sand was cored at the seep sites and clay or fine sediments were retrieved outside the seep sites from the parallel-stratified sediment cover. 
of the other landslides. Fig. 11 clearly demonstrates that the submarine landslide has moved into the canyon in front. The sub-surface data display that seeps occur within the submarine landslide in front of detached sediment ridges (Laberg and Vorren, 2000) originated from the mass movement.

The terrace on the central divide upslope of the submarine landslides (Fig. 11) consists of three radially spread ridges. Seeps are located on the crest of these ridges. The sub-surface data show similar features as in other areas (Fig. 12): i.e. parallel-stratified deposits occur on the sides of the ridges and thin out towards the seepfilled crests, the gas front domes up and approaches the sea floor within $<5 \mathrm{~m}$ beneath the seep locations on the crests of the ridges and a filled channel marks the upslope boundary of this seep area (Fig. 12, profile AB) and there is no evidence of faulting. During the 2004 METROL cruise (Poseidon cruise P317/3) profile 12 CD was used as a base for gravity coring (Borowski et al., 2005). Sand was retrieved at the seep sites at the top of the ridges and clayey sediments outside the seep sites in the parallelstratified sediment cover.

\section{Discussion}

\subsection{Pockmarks}

Since we detected hundreds of seeps in the elongated depressions on the shelf (Fig. 6), we interpret these as pockmarks, as defined by Hovland and Judd (1988). Pockmarks are crater-like structures that are formed by fluid expulsions, and occur worldwide on continental margins, generally in muddy sea beds. They are often associated with gas hydrates, slides and slumps (Hovland et al., 2002). Our bathymetric data show that the observed pockmarks appear to be an amalgamation of several smaller pockmarks (Fig. 6). Single, smaller pockmarks are about $100 \mathrm{~m}$ wide and $3 \mathrm{~m}$ deep (Fig. 6). The shallowness of the pockmarks is probably due to the relatively hard sea floor on the shelf, which consists of clayey sediments mixed with shells and shell debris. The high seep activity in the pockmarks is remarkable, as active i.e. bubbling - pockmarks are thought to be very scarce (Hovland et al., 2002). Less active pockmarks are deeper and better developed than the presently active ones. This could be a result of the self-sealing nature of seeps due to carbonate cementation as postulated by Hovland (2002). Except for the updoming gas front and the margins of the filled channels, there appear to be no other sub-surface structures which could be identified as potential factors controlling the pockmark and seep locations. The overall NWSE trend of seeps and pockmarks reflect the course of the underlying filled channels (Fig. 6).

\subsection{Crests of sedimentary ridges}

The alignment of the seeps on the crests of the sedimentary ridges, the general morphology of the crests (upslope-downslope trend) (Figs. 5 and 10) and the absence of faults suggest that the ridges are formed purely by differential erosion. More erosion-resistant sediments will stand out in relief after periods of erosion and result in the typical shape of the ridges. Because of the obvious seep-crest relationship and the sub-surface features below the crests (updoming gas front, parallel stratified cover that thins out towards the crest, gas front that stays below this cover) (Fig. 10), we postulate that the alignment of seeps on the crest of the ridges is probably linked to a process described by Hovland (1990, 1992). He proposed that the gas permeating from gas-bearing sediments below into a relatively thick unit of plastic clay, covering the gas-bearing sediments, causes those sediments to be buoyed up so that they form elongated ridges on the surface. This process could have breached the cover of fine sediments that acted as a stratigraphic seal permitting and also focusing seepage at the crests of the ridges. Since the ridges in our study area are sometimes up to $100 \mathrm{~m}$ high, the proposed process can only account for the alignment of the seeps at the crests and probably not for the formation of the ridges as a whole.

Since seepage is commonly associated with precipitation of methane-derived authigenic carbonates (Boetius et al., 2000; Michaelis et al., 2002), seeps probably have also contributed to the formation of more erosionresistant sediment on the crests of these ridges.

\subsection{Canyons}

The floors and walls of most canyons in our study area are strongly affected by mass wasting (Figs. 1012). Mass-wasting on canyon floors and walls creates fresh scars and breaches the fine-grained sediment cover that effectively functions as a stratigraphic seal. As a result, possible gas-bearing layers get exposed and facilitate gas seepage at these scarred steep canyon walls. That seepage commonly occurs on steep, recently eroded sea floor was also observed in Monterey Bay (Paull et al., 2005). If the fine-grained cover is not affected by mass-wasting, fluids tend to be focused upslope to the margins of the canyon where the cover diminishes and seepage can occur (Fig. 12). These 
inferred fluid migration patterns are in agreement with the observed behavior of the gas front. Migration of fluids can also be focused by faults, but on our data, no faults affect the upper $250 \mathrm{~m}$ of the sediment column in the vicinity of canyons and below seeps. Therefore, we rule out faults as the main conduits for fluid migration close to the sea floor. This does not exclude that deeper faults, such as e.g. those observed by Lüdmann et al. (2004), might have influenced the position of the existing canyons and cause a pre-focusing of deeper derived fluids.

\subsection{Submarine landslides}

Differences exist in seep distribution associated with submarine landslides in the erosion-dominated area and in the deposition-dominated area. In the mass-wasting dominated area, the linear alignment of the scarps and the seeps suggest a structural control that determines the seep locations and the morphology of the submarine landslides. Helium analyses of water samples from this area sustain this suggestion by showing anomalous high ${ }^{3} \mathrm{He}$ values which point to an input from deepderived fluids (Holzner et al., 2005). A potential link between sub-surface structures and mass wasting was already suggested by several authors for other areas (Orange and Breen, 1992; Eichhubl et al., 2000; Kuşçu et al., 2004). Mass-wasting may be triggered by upward migration of fluids along faults resulting in a reduction in slope stability (Orange et al., 1997). The close relation of seepage and scarps can be explained by steepened pore-pressure gradients adjacent to scarps due to sudden erosion associated with slumping and the resulting focusing of fluid towards these scarps (Orange et al., 1997). Seepage is commonly observed at recently eroded sea floor. The different morphological expression and different distribution of seeps in relation to the submarine landslide in the deposition-dominated area suggest a different mechanism for sediment mass movement and associated seepage (Fig. 11). At the double submarine landslide we do not observe seepage at the scarps, but only in front of detached sediment ridges originated from the mass movement (Fig. 11). The landslide morphology and seep distribution can be the result of high water and gas contents of the sediments, which, together with the relatively steep slope, caused sediment destabilization and the observed mass movement. The seepage itself is probably a consequence of higher sediment compaction and steepened pore-pressure gradients in front of the detached sediment ridges. Since the BGHSZ is outcropping at the base of both landslide areas we have to take into account that the sediment failure could have been facilitated by gashydrate destabilization due to temperature and pressure changes associated with climatically driven sea-level fluctuations (Poort et al., 2005), as has also been proposed for e.g. Storegga slide (Bouriak et al., 2000; Bünz et al., 2005). We do not observe any seepage through the GHSZ in the vicinity of these landslides that could result from overpressure and steeper pore-pressure gradients due to extra sedimentary loading or erosion at the base of the submarine landslides.

\subsection{Terrace}

As the terrace on the central divide consists of three radially spread seeping ridges, we suggest the same mechanism for the seep-crest relation as is proposed for the other sedimentary ridges on the slope. However, judging from the shape, the size and the position of the terrace, the ridges here are not common upslope-downslope ridges, like the other seep-marked ridges on the slope. The lobed morphology of the terrace with the central ridges is reminiscent of a lobed delta front with tributaries (Prior and Bornhold, 1990). We therefore propose that the terrace originated from an old delta front in which coarse sediments were deposited during a period of sea-level lowstand and that these coarser sediments currently act as highly permeable stratigraphic horizons that facilitate fluid migration and seepage at the sea floor. This is also indicated by coring (2004 METROL cruise) (Borowski et al., 2005). Since the terrace is located in a paleo-delta environment this hypothesis can indeed be valid, were it not that the water level would have had to be $180 \mathrm{~m}$ below current water level. This is $30 \mathrm{~m}$ lower than the lowest value proposed in literature for the last lowstand in the Black Sea (Winguth et al., 2000). Peckmann et al. (2001) have dated carbonates from the terrace with an age of $19 \mathrm{ka}$ BP. This indicates that seepage at the terrace was already active during the last lowstand $20 \mathrm{ka}$ ago (Aksu et al., 2002) and that the terrace thus represents a remnant from the last or from a previous lowstand.

\subsection{Controls on seep distribution}

The most important control on seep distribution, or rather on the absence of seeps in the study area, is the presence of gas hydrates (Figs. 8 and 13), which have often been inferred to have the capacity to act as a buffer for upward migrating gas (Kvenvolden, 1998). Gas hydrates are theoretically stable and have directly and indirectly been observed in $585 \mathrm{~km}^{2}$ of the $1540 \mathrm{~km}^{2}$ covered study area. However, only $0.5 \%$ of the 2778 


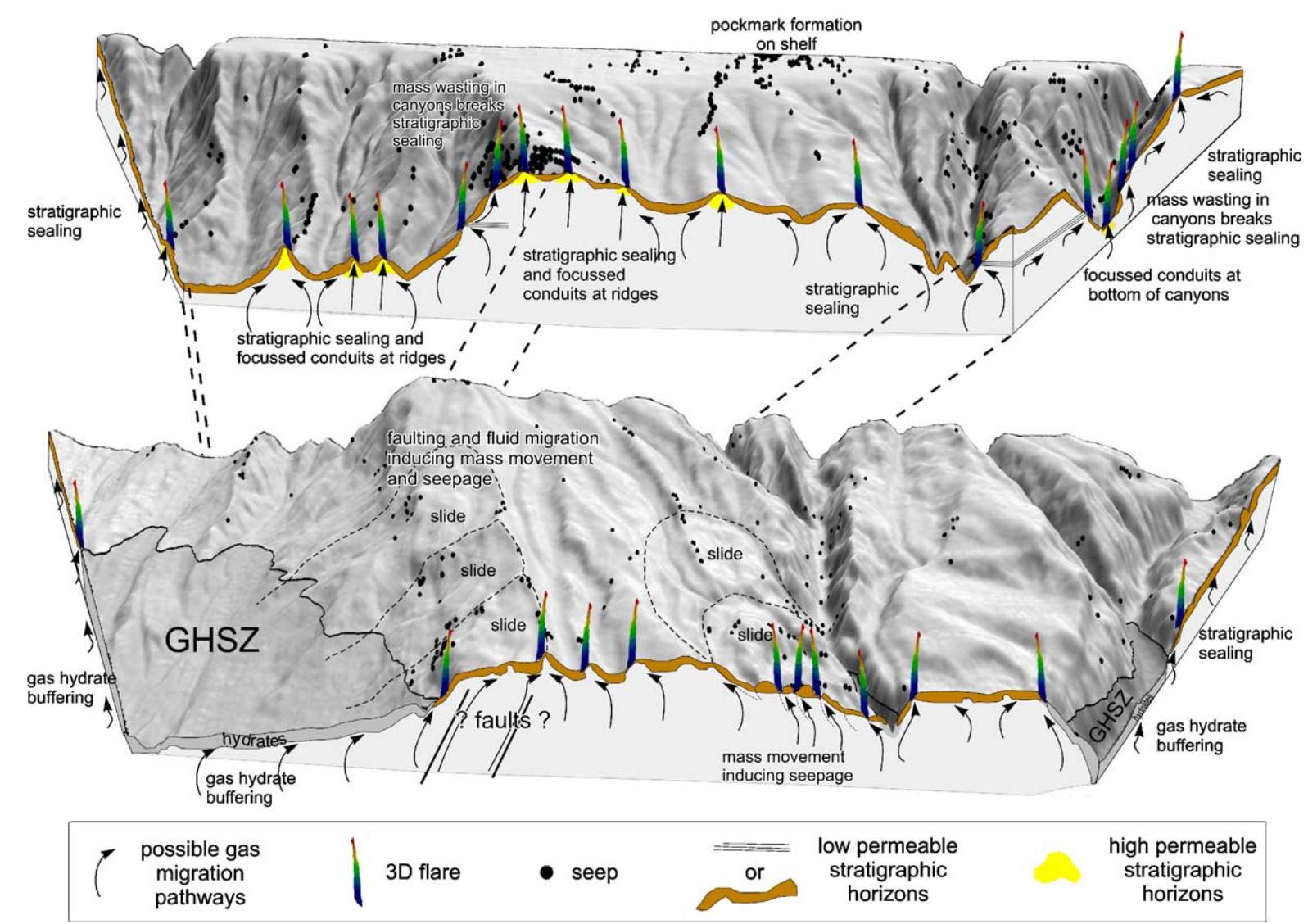

Fig. 13. Combining model of the supposed fluid migration in the subsurface and its expression at the seafloor surface. The 3D block diagram based on the bathymetric data, seep positions and subsurface data presenting a model for the seep distribution in the Dnepr paleo-delta for the shallowwater seep sites (top) and the deep-water seep sites, with submarine landslides and gas hydrates (bottom).

detected seeps are located in the GHSZ, even though the presence of sub-surface gas is indicated (i.e. by enhanced reflections below the BSR) (Figs. 8 and 13).

Outside the GHSZ, based on the absence of faults below almost all studied seep sites, we propose that seepage in our study area is determined mainly by stratigraphic and sedimentary controls (Fig. 13). A thick impermeable sedimentary cover focuses the migration of fluids to nearby morphological highs, where this impermeable sedimentary cover of fine-grained sediments is breached by the process proposed by Hovland (1990, 1992) (Fig. 13). The almost complete absence of seeps above the finer-grained levee and overbank deposits confirm the sealing capacity of the sedimentary cover (Fig. 13). It is only where this seal is destroyed by mass wasting or erosion that seepage occurs (Fig. 13). The sub-bottom depth distribution of the gas front confirms the sealing capacity of gas hydrates and of the finegrained sedimentary cover in our study area.

A possible structural control on seepage can only be suggested for the seeps located on the scarps of the submarine landslide in the mass-wasting dominated area. However, the influence of possible gas-hydrate destabilization at the foot of the submarine landslides and the associated gas seeps cannot be neglected (Fig. 13).

\section{Conclusions}

Based on $5621 \mathrm{~km}$ of echosounder tracks we were able to detect 2778 active seeps within the $1540 \mathrm{~km}^{2}$ of the studied Dnepr paleo-delta area. The integration of the geophysical datasets clearly indicates that methane seeps are not randomly distributed in this area, but are concentrated in specific locations. The depth limit for $99.5 \%$ of the detected seeps coincides with the phase boundary of pure methane hydrate at $725 \mathrm{~m}$ water depth. This suggests that gas hydrates act as an effective seal and prevent upward migrating methane gas to be released as bubbles into the water column. Elsewhere, seeps generally occur in association with pockmarks on the continental shelf, along crests of sedimentary ridges, at bottoms, flanks and margins of canyons and 
near submarine landslides on the continental slope. Except for one, all these areas are characterized by the absence of faults. This does not support the hypothesis by Kruglyakova et al. (2004) that seepage is primarily associated with tectonically driven flows through regional faults in the Dnepr paleo-delta area. Our data, on the contrary, are in agreement with observations in Monterey Bay where seepage appears to be primarily associated with morphologically or stratigraphically controlled flow (Yun et al., 1999; Paull et al., 2005), and this can probably be extended to other continental margins worldwide. The stratigraphic and sedimentary control on the distribution of methane seeps is demonstrated by the absence of seeps above parallel-stratified fine-grained deposits (low-permeability stratigraphic horizons). The sealing capacity of gas hydrates and fine-grained sediment covers gets emphasized by the regional behavior of a distinct sub-bottom gas front that domes up to the sea floor in areas where bubbles were detected in the water column and where the abovementioned seals are locally absent or negligible. Finally, we can conclude that in the studied Dnepr paleo-delta, seep locations are mainly determined by sedimentary characteristics close to the sea floor and that seepageproducing subsurface features and fluid migration can influence the sea-floor morphology by forming pockmarks and causing sediment instabilities.

\section{Acknowledgements}

We thank the captain and the crew of the 58th and 60th cruise of $R V$ Professor Vodyanitskiy for their hard work and their hospitality and L3 communications ELAC Nautik for their superior and fast support. This study was carried out in the framework of the CRIMEA project (EC project EVK2-200200162; http://www.CRIMEA-info.org). Extra data were contributed by the METROL project (EC project EVK3-2002-00080) and GHOSTDABS project (German Federal Ministry of Education and Research project 03G0559A). We also like to thank SMT (Kingdom Suite) and IVS (Fledermaus) for the academic licenses. Finally, we thank Martin Hovland and Maarten Vanneste for their constructive reviews which helped improve this manuscript.

\section{References}

Aksu, A.E., Hiscott, R.N., Yasar, D.F., Isler, I., Marsh, S., 2002. Seismic stratigraphy of Late Quaternary deposits from the southwestern Black Sea shelf: evidence for non-catastrophic variations in sea-level during the last $\sim 10000$ yr. Mar. Geol. 190 (1-2), $61-94$.
Amouroux, D., Roberts, G., Rapsomanikis, S., Andreae, M.O., 2002. Biogenic gas $\left(\mathrm{CH}_{4}, \mathrm{~N}_{2} \mathrm{O}\right.$, DMS $)$ emission to the atmosphere from near-shore and shelf waters of the northwestern Black Sea. Estuar. Coast. Shelf Sci. 54, 575-587.

Anderson, A.L., Hampton, L.D., 1980. Acoustics of gas bearing sediment. J. Acoust. Soc. Am. 67, 1865-1903.

Boetius, A., Revenschlag, K., Schubert, C.J., Rickert, D., Widdel, F., Gieseke, A., Armann, R., Jørgensen, B.B., Witte, U., Pfannkuche, O., 2000. A marine microbial consortium apparently mediating anaerobic oxidation of methane. Nature 407, 623-626.

Borowski, C., Joergensen, B.B., The Poseidon 317/3 Shipboard party, 2005. Gas-charged sediments, methane seeps and carbonate-precipitating microbial mats on the NW Black Sea Shelfpreliminary results of research project METROL from a cruise using the manned submersible JAGO. Geophys. Res. Abstr. 7, 09603.

Bouriak, S., Vanneste, M., Saoutkine, A., 2000. Inferred gas hydrates and clay diapirs near the Storegga Slide on the southern edge of the Vøring Plateau, offshore Norway. Mar. Geol. 163, $125-148$.

Bünz, S., Mienert, J., Bryn, P., Berg, K., 2005. Fluid flow impact on slope failure from 3D seismic data: a case study in the Storegga Slide. Basin Res. 17, 109-122.

Campbell, K.A., Farmer, J.D., Des Marais, D., 2002. Ancient hydrocarbon seeps from the Mesozoic convergent margin of California: carbonate geochemistry, fluids and palaeoenvironments. Geofluids 2, 63-94.

Egorov, V.N., Luth, U., Luth, C., Gulin, M.B., 1998. Gas seeps in the submarine Dniepr paleo-delta, Black Sea: acoustic video and trawl data. Ber. aus den ZMK, Reihe E. 14, 11-22.

Eichhubl, P., Green, H.G., Naeher, T., Maher, N., 2000. Structural control of fluid flow: offshore fluid seepage in the Santa Barbara Basin, California. J. Geochem. Explor. 69-70, 545-549.

Finetti, I., Bricchi, G., Del Ben, A., Pipan, M., Xuan, Z., 1988. Geophysical study of the Black Sea. Boll. Geofis. Teor. Appl. 30, 197-324.

Garcia-Gil, S., Vilas, F., Garcia-Garcia, A., 2002. Shallow gas features in incised-valley fills (Ria de Vigo, NW Spain): a case study. Cont. Shelf Res. 22, 2303-2315.

Greinert, J., Bohrmann, G., Suess, E., 2001. Methane-venting and gas hydrate-related carbonates at the Hydrate Ridge: their classification, distribution and origin. In: Paull, C.K., Dillon, W.P. (Eds.), Natural Gas Hydrates: Occurrence, Distribution, and Detection, Geophysical Monograph, vol. 124, pp. 99-113.

Greinert, J., Bollwerk, S.M., Derkachev, A., Bohrmann, G., Suess, E., 2002. Massive barite deposits and carbonate mineralization in the Derugin Basin, Sea of Okhotsk: precipitation process at cold vent sites. Earth Planet. Sci. Lett. 203, 165-180.

Holbrook, W.S., 2001. Seismic studies of the Blake Ridge: implications for hydrate distribution, methane expulsion and free gas dynamics. In: Paull, C.K., Dillon, W.P. (Eds.), Natural Gas Hydrates: Occurrence, Distribution and Detection. Geophysical Monographs. American Geophysical Union, pp. 235-256.

Holzner, C.P., Amaral, H., Brennwald, M.S., Hofer, M., Klump, S., Kipfer, R., 2005. Methane bubble streams in the Black Sea traced by dissolved noble gases. Geophys. Res. Abstr. 7, 03846.

Hornafius, J.S., Quigley, D., Luyendyk, B.P., 1999. The world's most spectacular marine hydrocarbon seeps (Coal Oil Point, Santa Barbara Channel, California): quantification of emission. J. Geophys. Res. 104, 20703-20711.

Hovland, M., 1990. Suspected gas-associated clay diapirism on the seabed off Mid Norway. Mar. Pet. Geol. 7, 267-276. 
Hovland, M., 1992. Hydrocarbon seeps in northern marine waterstheir occurrence and effects. Palaios 7, 376-382.

Hovland, M., 2002. On the self-sealing nature of marine seeps. Cont. Shelf Res. 22, 2387-2394.

Hovland, M., Curzi, P., 1989. Gas seepage and assumed mud diapirism the Italian Central Adriatic Sea. Mar. Pet. Geol. 6, $161-169$.

Hovland, M., Judd, A.G., 1988. Seabed Pockmarks and Seepages. Graham and Trotman, London. 293 pp.

Hovland, M., Talbot, M., Olaussen, S., Aasberg, L., 1985. Recently formed methane-derived carbonates from the North Sea floor. In: Thomas, B.M. (Ed.), Petroleum Geochemistry in Exploration of the Norwegian Shelf. Norwegian Petroleum Soc., Graham and Trotman, pp. 263-266.

Hovland, M., Gardner, J.V., Judd, A.G., 2002. The significance of pockmarks to understanding fluid flow processes and geohazards. Geofluids 2, 127-136.

Johnson, J.E., Goldfinger, C., Suess, E., 2003. Geophysical constraints on the surface distribution of authigenic carbonates across the Hydrate Ridge region, Cascadia margin. Mar. Geol. 202, 79-120.

Jørgensen, B.B., Böttcher, M.E., Lüschen, H., Neretin, L.N., Volkov, I.I., 2004. Anaerobic methane oxidation and a deep $\mathrm{H}_{2} \mathrm{~S}$ sink generate isotopically heavy sulfides in Black Sea sediments. Geochim. Cosmochim. Acta 68, 2095-2118.

Judd, A.G., 2003. The global importance and context of methane escape from the seabed. Geo Mar. Lett. 23, 147-154.

Judd, A.G., Hovland, M., 1992. The evidence of shallow gas in marine sediments. Cont. Shelf Res. 12 (10), 1081-1095.

Judd, A.G., Davies, G., Wilson, J., Holmes, R., Baron, G., Bryden, J., 1997. Contributions to atmospheric methane by natural seepages on the UK continental shelf. Mar. Geol. 137, 165-189.

Judd, A.G., Hovland, M., Dimitrov, L.I., Garcia Gil, S., Jukes, V., 2002. The geological budget at Continental Margins and its influence on climate change. Geofluids 2, 109-126.

Krastel, S., Spiess, V., Ivanov, M., Weinrebe, W., Bohrmann, G., Shashkin, P., Heidersdorf, F., 2003. Acoustic investigations of mud volcanoes in the Sorokin Trough, Black Sea. Geo Mar. Lett. 23, 230-238.

Kruglyakova, R.P., Byakov, Y.A., Kruglyakova, M.V., Chalenko, L.A., Shevtsova, N.T., 2004. Natural oil and gas seeps on the Black Sea floor. Geo Mar. Lett. 24, 150-162.

Kuşçu, I., Okamura, M., Matsuoka, H., Gökasan, E., Awata, Y., Tur, H., Simsek, M., Keçer, M., 2004. Seafloor gas seeps and sediment failures triggered by the August 17, 1999 earthquake in the Eastern part of the Gulf of Izmit, Sea of Marmara, NW Turkey. Mar. Geol. 215 (3-4), 193-214.

Kvenvolden, K.A., 1993. Gas hydrates as a potential energy resource-a review of their methane content. In: Howell, D.G. (Ed.), The Future of Energy Gases-U.S. Geological Survey Professional Paper 1570. United States Government Printing Office, Washington, pp. 555-561.

Kvenvolden, K.A., 1998. A primer on the geological occurrence of gas hydrate. In: Henriet, J.P., Mienert, J. (Eds.), Gas Hydrates: Relevance to World Margin Stability and Climate Change, Geological Society Special Publication, vol. 137, pp. 9-30.

Laberg, J.S., Vorren, T.O., 2000. The Trænadjupet Slide, offshore Norway-morphology, evacuation and triggering mechanisms. Mar. Geol. 171, 95-114.

Lee, M.W., Dillon, W.P., 2001. Amplitude blanking related to the pore-filling of gas hydrate in sediments. Mar. Geophys. Res. 22, $101-109$.
Lüdmann, T., Wong, H.K., Konerding, P., Zillmer, M., Petersen, J., Flüh, E., 2004. Heat flow and quantity of methane deduced from a gas hydrate field in the vicinity of the Dnieper Canyon, northwestern Black Sea. Geo Mar. Lett. 24, 182-193.

Luth, C., Luth, U., Gebruk, A.V., Thiel, H., 2000. Methane gas seeps along the oxic/anoxic gradient in the Black Sea: manifestations, biogenic sediment compounds and preliminary results on benthic ecology. Mar. Ecol. 20, 221-249.

Michaelis, W., Seifert, R., Nauhaus, K., Treude, T., Thiel, V., Blumenberg, M., Knittel, K., Gieseke, A., Peterknecht, K., Pape, T., Boetius, A., Amann, R., Jørgensen, B.B., Widdel, F., Peckmann, J., Pimenov, N.V., Gulin, M.B., 2002. Microbial reefs in the Black Sea fuelled by anaerobic oxidation of methane. Science 297, $1013-1015$.

Moore, J.C., Brown, K.M., Horath, F., Cochrane, G., MacKay, M., Moore, G., 1991. Plumbing accretionary prisms. In: Tarney, J., Pickering, K.T., Knipe, R.J., Dewey, J.F. (Eds.), The Behavior and Influence of Fluids in Subduction Zones. The Royal Society, London, pp. 49-62.

Nikishin, A.M., Korotaev, M.V., Ershov, A.V., Brunet, M.-F., 2003. The Black Sea basin: tectonic history and Neogene-Quaternary rapid subsidence modeling. Sediment. Geol. 156, 149-168.

Orange, D.L., Breen, N.A., 1992. The effects of fluid escape on accretionary wedges: 2. Seepage force, slope failure, headless submarine canyons, and vents. J. Geophys. Res. 97, 9277-9295.

Orange, D.L., Anderson, R.S., Breen, N.A., 1994. Regular canyon spacing in the submarine environment: the link between hydrology and geomorphology. GSA Today 4, 29-39.

Orange, D.L., McAdoo, B.G., Screaton, E., Chezar, H., Lee, H., Reid, M., Vail, R., 1997. Headless submarine canyons and fluid flow on the toe of the Cascadia accretionary complex. Basin Res. 9, 313-324.

Orange, D.L., Yun, J.W., Maher, N., Barry, J., Green, G., 2002. Tracking California seafloor seeps with bathymetry, backscatter and ROV's. Cont. Shelf Res. 22, 2273-2290.

Paull, C.K., Schlining, B., Ussler, W., Paduan, J., Caress, D., Greene, H.G., 2005. Distribution of chemosyntectic biological communities in Monterey Bay, California. Geology 33, 85-88.

Peckmann, J., Reimer, A., Luth, U., Hansen, B.T., Heinicke, C., Hoefs, J., Reitner, J., 2001. Methane-derived carbonates and authigenic pyrite from the northwestern Black Sea. Mar. Geol. 177, 129-150.

Polikarpov, G.G., Egorov, V.N., Nezhdanonv, A.I., Gulin, S.B., Kulev, Yu.D., Gulin, M.B., 1989. Methane gas seeps in the Black Sea-a new object of molismology. In: Polikarpov, G.G. (Ed.), Molismology of the Black Sea. Nauka, Kiev, pp. 10-20.

Polikarpov, G.G., Egorov, V.N., Gulin, S.B., Gulin, M.B., Stokozov, N.A., 1992. Gas seeps from the bottom of the Black Sea-a new object of molismology. In: Polikarpov, G.G. (Ed.), Molismology of the Black Sea (in Russian). Nauka, Kiev, pp. 10-28.

Poort, J., Vassilev, A., Dimitrov, L., 2005. Did postglacial catastrophic flooding trigger massive changes in the Black Sea gas hydrate reservoir. Terra Nova 17 (2), 135-140.

Popescu, I., De Batist, M., 2004. Gas and hydrates in the Black Sea. EUROCEAN 2004 European Conference "Marine Science and Ocean Technology," Galway (Ireland), 10-13 May 2004.

Popescu, I., Lericolais, G., Panin, N., Wong, H.K., Droz, L., 2001. Late Quaternary channel avulsions on the Danube deep-sea fan. Black Sea. Mar. Geol. 179, 25-37.

Popescu, I., Lericolais, G., Panin, N., Normand, A., Dinu, C., Le Drezen, E., 2004. The Danube submarine canyon (Black 
Sea): morphology and sedimentary processes. Mar. Geol. 206, $249-265$.

Prior, D.B., Bornhold, B.D., 1990. The underwater development of Holocene fan deltas. In: Colella, A., Prior, D.B. (Eds.), Coarse-grained Deltas, Special Publication of the International Association of Sedimentologists, vol. 10. Blackwell Scientific Publications, pp. $75-90$.

Reeburgh, W.S., Whalen, S.C., Alperin, A.J., 1993. The role of methylotrophy in the global methane budget. In: Murrel, J.A., Kelley, D.P. (Eds.), Microbial Growth on C-1 Compounds. Intercept, Andover, UK, pp. 1-14.

Richardson, M.D., Davis, A.M., 1998. Modeling methane-rich sediments of Eckernförde Bay. Cont. Shelf Res. 18, 1671-1688.

Robinson, A.G., Rudat, J.H., Banks, C.J., Wiles, R.L.F., 1996. Petroleum geology of the Black Sea. Mar. Pet. Geol. 13, $195-223$.

Ryan, B.F., Pitman, W.C., Major, C.O., Shimkus, K., Moskalenko, V., Jones, G.A., Dimitrov, P., Gorür, N., Sakinç, M., Yüce, H., 1997. An abrupt drowning of the Black Sea shelf. Mar. Geol. $138,119-126$.

Sills, G.C., Wheeler, S.J., 1992. The significance of gas for offshore operations. Cont. Shelf Res. 12, 1239-1250.

Sloan, E.D., 1990. Clathrate Hydrates of Natural Gases. Marcel Dekker, Inc, New York. 641 pp.

Suess, E., Torres, M.E., Bohrmann, G., Collier, R.W., Rickert, D., Goldfinger, C., Linke, P., Hauser, A., Sahling, H., Heeschen, K., Jung, C., Nakamura, K., Greinert, J., Pfannkuche, O., Trehu, A., Klinkhammer, G., Whiticar, M.J., Eisenhauer, A., Teichert, B., Elvert, M., 2001. Sea floor methane hydrates at Hydrate Ridge, Cascadia Margin. In: Paull, C.K., Dillon, W.P. (Eds.), Natural Gas Hydrates: Occurrence, Distribution, and Detection, Geophysical Monograph, vol. 124. AGU, pp. $87-98$.

Thiel, V., Peckmann, J., Richnow, H.-H., Luth, U., Reitner, J., Michaelis, W., 2001. Molecular signals for anaerobic methane oxidation in Black Sea seep carbonates and microbial mats. Mar. Chem. 73, 97-112.

Van Rensbergen, P., De Batist, M., Klerkx, J., Hus, R., Poort, J., Vanneste, M., Granin, N., Khlystov, O., Krinitsky, P., 2002. Sublacustrine mud volcanoes and methane seeps caused by dissociation of gas hydrates in Lake Baikal. Geology 30, 631-634.

Vanneste, M., De Batist, M., Golmshtok, A., Kremlev, A., Versteeg, W., 2001. Multi-frequency seismic study of gas hydrate-bearing sediments in Lake Baikal, Siberia. Mar. Geol. 172, 1-21.

Wever, T.F., Abegg, F., Fiedler, H.M., Fechner, G., Stender, I.H., 1998. Shallow gas in the muddy sediments of Eckernförde Bay, Germany. Cont. Shelf Res. 18, 1715-1739.

Winguth, C., Wong, H.K., Panin, N., Dinu, C., Georgescu, P., Ungureanu, G., Krugliakov, V.V., Podshuveit, V., 2000. Upper quaternary water level history and sedimentation in the northwestern Black Sea. Mar. Geol. 167, 127-146.

Wong, H.K., Lüdmann, T., Panin, N., Konerding, P., Dinu, C., 2002. Northwestern Black Sea: Upper Quaternary water level and sedimentation. In: Briand, F. (Ed.), Turbidite Systems and Deep-Sea Fans of the Mediterranean and the Black Seas, CIESM Workshop series, vol. 17. Monaco, pp. 85-89.

Yun, J.W., Orange, D.L., Field, M.E., 1999. Subsurface gas offshore of northern California and its link to submarine geomorphology. Mar. Geol. 154, 357-368.

Zillmer, M., Flueh, E.R., Petersen, J., 2005. Seismic investigation of a bottom simulating reflector and quantification of gas hydrate in the Black Sea. Geophys. J. Int. 161, 662-678. 